
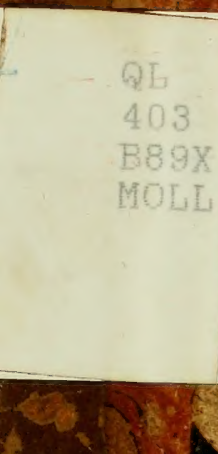

A

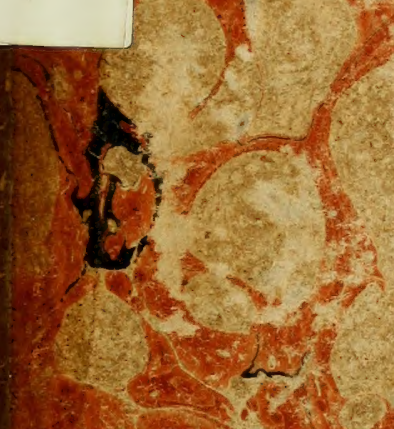

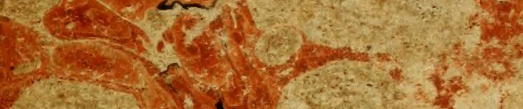

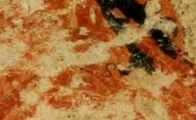

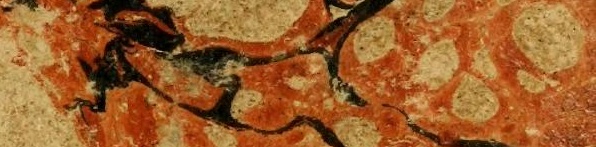

tis

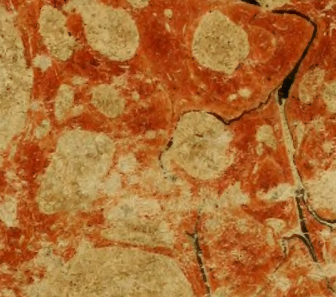

(1)

I. $25-2 x^{2}$

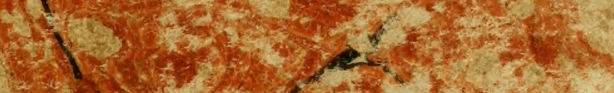

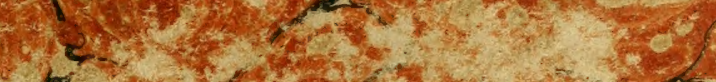

r. $x^{2}-2=1$

A. $-4, y+2$ ?

$x+2 y 3 x-3=4$

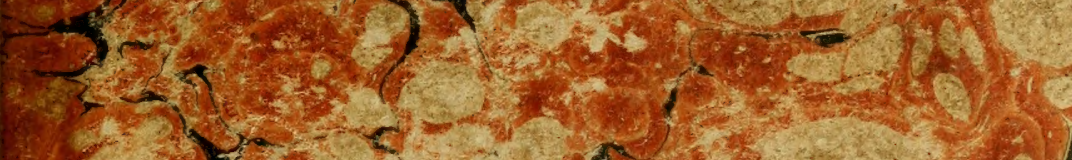

$=x^{2}=2-62 x+10$ b. $60-15=0$

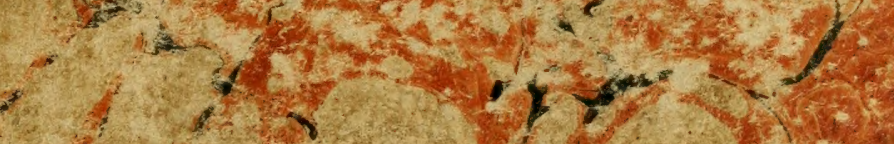

$x^{2}+x^{2}+2 y$

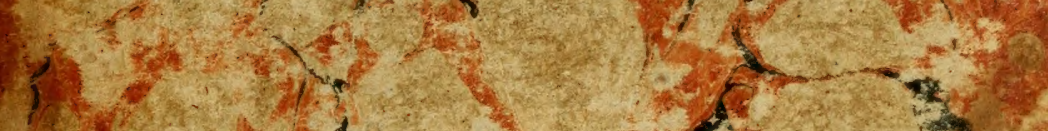

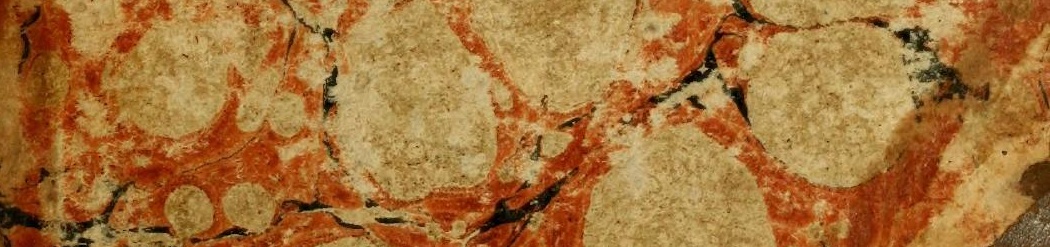




\section{4}

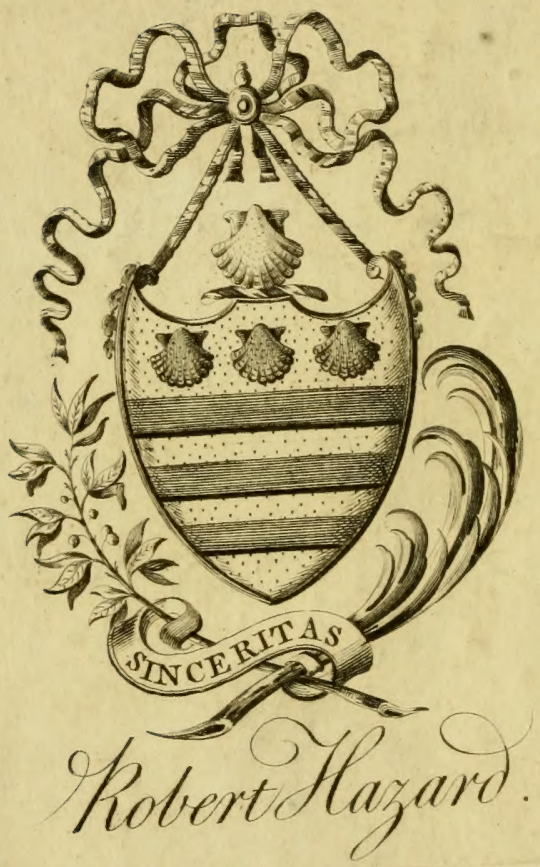


T:Hi Flazance

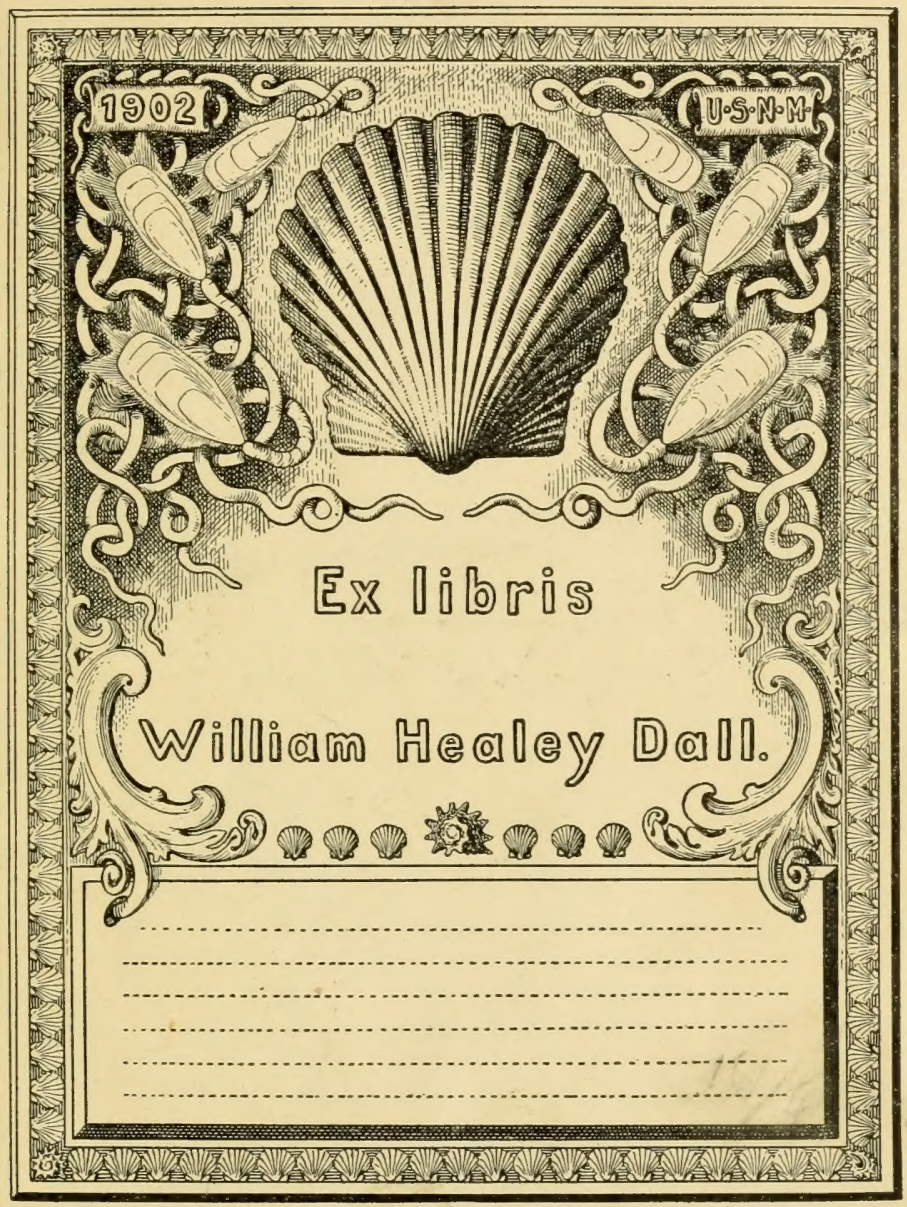



I Brown, $T$. 

I BROWN, T. 


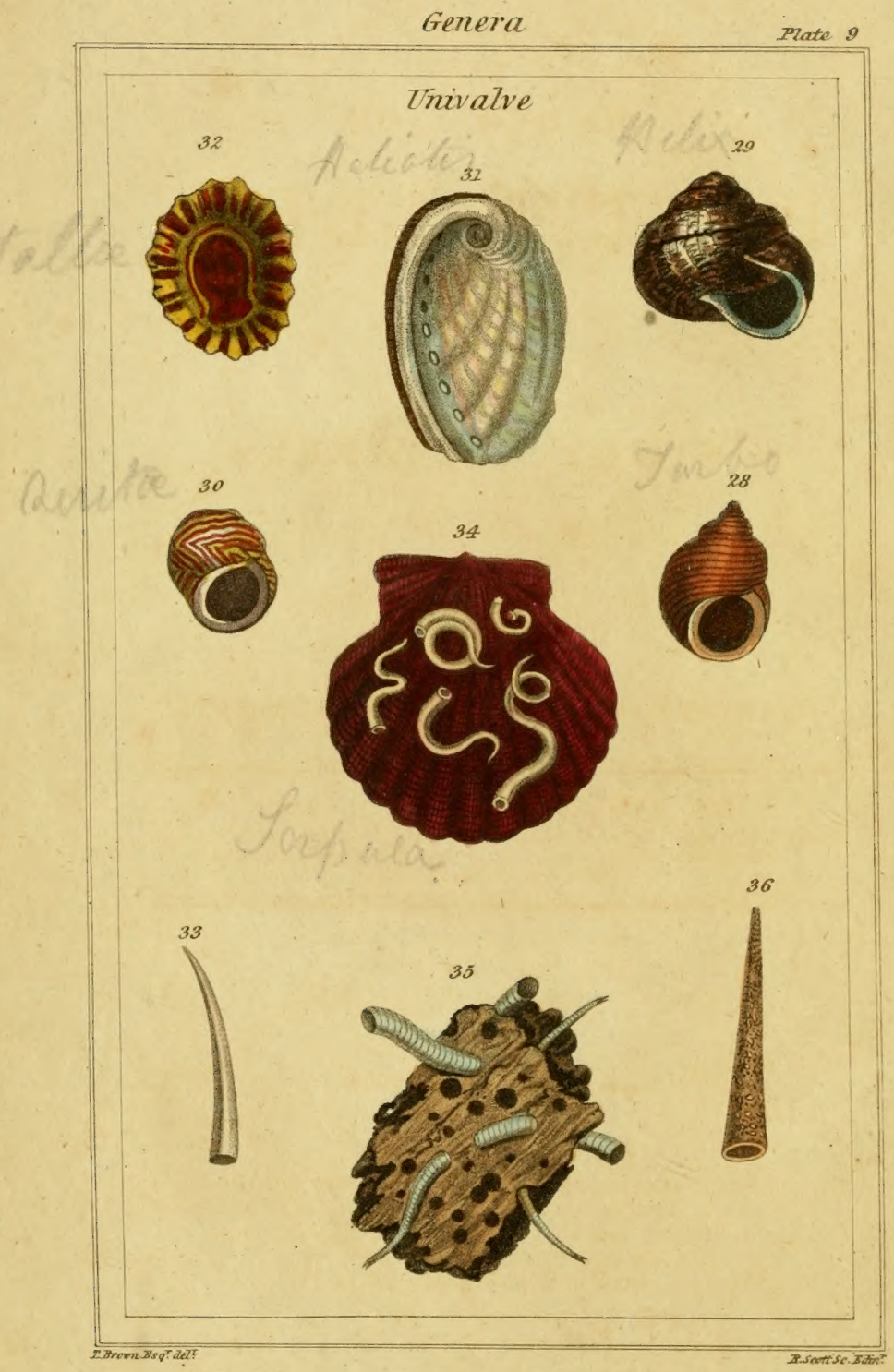


Thu fienry tazond wansea flamogansaxic

\title{
Division of Mollusites
}

THE

\section{ELEMENTS OF}

\section{CONCEIOLOAY: \\ OR}

NATURAL

\section{HISTORY OF SHELLS :}

\author{
ACCORDING TO \\ The Limmeam Sustem.
}

WITH

OBSERVATIONS ON MODERN ARRANGEMENTS.

BY THOMAS BROWN, ESQ.

Captain Forfar Regt. Fellow of the Linnean Society, Member of the Wernerian

Natural History Society, and Honorary Member of the Literary and

Philosophical Society of Bolton.

ILLUSTRATED WITH

NINE COLOURED ENGRAVINGS.

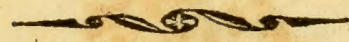

Lantarn:

PZINTED POR LACKINGTON, ALLEN, \& CO. TINSBURY SQUARE;

LONGMAN, HURST, REES, ORME, AND BROWN, RATER-

NOSTER ROW; JOHN MURRAY, ALBEMARLE STRIET;

ARCHIBALD CONSTABLE AND CO. EDINBURGH;

AND JOHN CUMMING, ORMOND QUAY,

DUBLIN.

J. Gleave, Printer.

1816. 


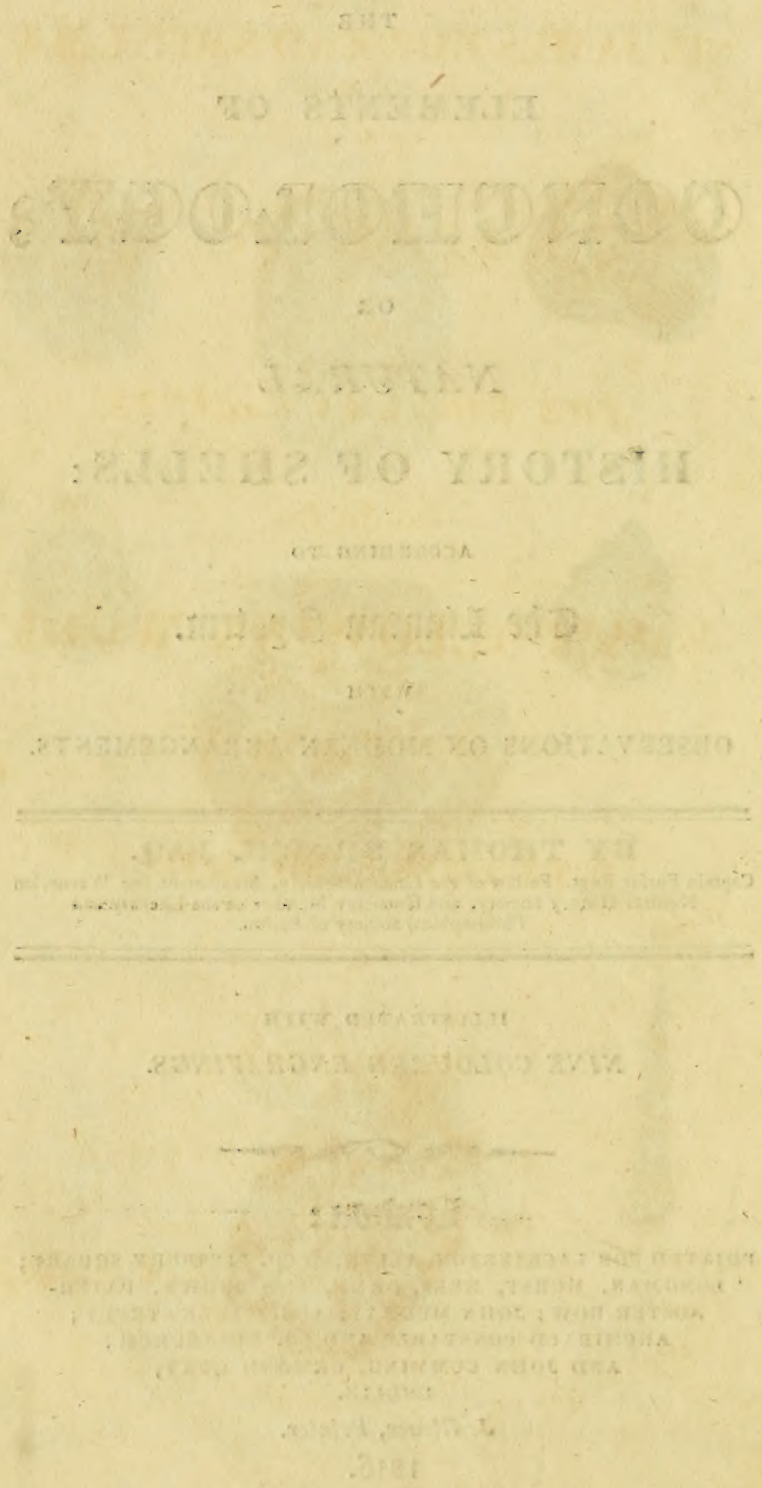


To

\title{
SIR JAMES EDWARD SMITH, M.D.
}

\author{
F. R.S.
}

\section{PRESIDENT}

OF

TIE LINNEAN SOCIETY,

$$
\& c . \& c . \& \% \text {. }
$$

\section{THE FOLLOWING WORK}

\author{
IS INSCRIBED,
}

WITH ESTEEII AND RESPECT,

$$
\text { vY }
$$

HIS MOST OBEDIENT,

IUUMBL SERVANT,

Cbe authat. 



\section{Mreface.}

THE intention of the following work is to lay before the student, in the simplest style, the Linnean urrangement of shells.

The author was induced to undertake this simple zork, becuuse there wus no elementary book on shells in the English language, with the exception of $D a$ Casta's, whose arrangement is now generally exploded. The work now presented to the public is strictly according to the Linnean System.

Several attempts have been made, to overturn the Limnean arrangement of shells, but without effect. And with all its pretended fuults no one has been able to supercede it, by a better system. That it is not so complete as the other departments, most people are ready to allow; but its beauties must perpetuate its pre-eminence.

In describing the genera, the author has also pointed out the different alterations of modern arrangements, (particularly that of Lamarck;) and the new genera which they have formed. And it has been his olject to illustrate the work, as far as it was possible, by figures of British shells; which will facilitate the study of British Testaceology, and prove equally useful to the study of General. Conchology. 



\section{CONTENTS:}

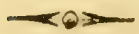

Intronuction to the science.

The animals which have been discovered to inhabit shells

Explanation of the parts of shells.

Multivalve 13

Bivalve

Univalve

\section{Of genera.}

Order 1st. Multivalve shells....................... $4 \mathcal{Q}$

— 2nd. Bivalve shells .......................... 47

- 3rd. Univalve shells with a regular spire... 65 Division 2nd. Shells without a regular spire...... 90

Specific description of the plates.

Plate 1st. Multivalve shells....................... is

Bivalve shells ........................... 102

- 2nd. Bivalve shells........................... 105

Univalve shells....................... 109

3rd. ........................................... 112

- 4th. Hinges of bivalves, \&c................ 119 


\section{CONTENTS.}

To illustrate the genera.

Plate 5th. Multivalve shells..................... 121

Bivalve shells ......................... ib

- 6 th. ...................................... ib

- 7 th. ........................................ 1 122

Univalve shells......................... ib

- 8th. ......................................... ib

- 9th. ...................................... 123

Eist of the principal books which treat of Conchology.................................... 124.

Method of cleaning sheils........................... 129

Simple method of arranging cabinets............. 13s

Explanation of terms used in the science of Conchology ....................................... 139 


\section{ERRATA.}

Page 4, line 13.-For Olearus read Olearius.

$7, \ldots . . .14 .-$ For probu read proper.

3,.... 19.-Erase the word 'none' at the beginning of the line.

$10, \ldots . . .20 .-$ For most read many.

$12, \ldots \ldots 12$. - For twelve read fourteen.

24,..... 12.-For Solina read Solen's.

31,..... 2,-For Adamson read Adanson.

32,..... 13. -Insert after \&c. Plate 2 nd, $E$ E.

$40, \ldots . . .5$.-For tooth-shape read tooth-shaped.

$41, \ldots \ldots$ \&2, - For $I$ read $Y$.

$47, \ldots . .5$. - Read hinge with $a$ broad, \&c。

$49, \ldots . . .15$. - For on one read in one.

$50, \ldots . . .6$ 6.-For Cyclus read Cyclas.

$56, \ldots . . .18$. - For Hippossus read Hippopus.

$58, \ldots . . .8$. - For Nuclia read Nucula.

$59, \ldots \ldots$ 14. - For species read genera.

$67, \ldots . .14$ and 15.-For Pitillæ read Patellæ.

$68, \ldots . . .9$ 9. - For Sephunculus read Siphunculus.

$75, \ldots . . .18$. For dentrila read detrita.

$81, \ldots . .14$. - For staincase read stair-case.

$88, \ldots . . .3$ 3.-For Gmelen read Gmelin.

$89, \ldots . . .2$. - For Casta read Costa.

$99, \ldots . . .21$. - For vermillion read vermilion.

$106, \ldots . . .9$ 9.-For is read are.

$110, \ldots . . .23 .-$ For five read fine.

$115, \ldots . . .13$. - After body, insert $O$ pillar-lip.

$117, \ldots . . .12 .-E r a s e$ " $N$ Spicula."

$126, \ldots . . .10$, - For Neurnberg read Neurembert. 



\section{OF \\ CONCHOLOGY.}

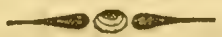

CONCHOlogr, is the science by which shells, or testaceous bodies, are properly arranged into systematic order.

On the face of our globe, the number of Natural Bodies, is so immense, that, on a general view, the human mind recoils from the investigation of them as impossible. But since the invention of systems, the task now appears at once practicable; and, indeed, every object can be traced, with certainty and facility, to its proper place in the System of Nature. 
In common language, the System of Nature has been divided into three kingdoms, viz. the Animal, Vegetable, and Pineral. 'That the young student may more easily understand the meaning of the classes, orders, \&c. into which these three kingdoms are divided, we shall conpare

A Class to an Army;

An Order to a Regiment;

A Genus to a Company;

And a Species to a Soldier.

When we find a natural body, we must first refer it to a class in the system of Nature, then to an order, next to a genus, and then we endeavour to ascertain its species.

All natural bodies, which agree in every particular, or essential property, are considered of the same species; for example, all dogs are specifically the same, but the difference between the hyena, wolf, fox, (though of the same genus as the dog Canis of Linné) and the pointer and 
spaniel, is so great as to constitute them of a different species; as is the bull-dog, mastiff, terrier, \&c. Dogs taken generally form a genus. So it is with all natural bodies.

A plurality of species, constitutes a genus; and many genera, constitutes an order; and several orders, a class; and a variety of classes, a kingdom.

The term Conchology includes all animals which have a testaceous covering, whether they inhabit the sea, land, or fresh-water.

By chenical analysis testaceous bodies have been found to consist of, carbonate of lime, mixed with gelatinous matter.

Chemists have divided shells into two classes. The first are usually of a compact texture, resembling porcelain, and have an enamelled surface, and are in general beautifully variegated. Those composing this class 
are called porcelanaccous shells. To this class belong various species of conus, cypraa, voluta, \&c.

The second class consists of shells generally covered with a strong epidermis or skin, below which lies the shell in layers, and composed entirely of the substance well known by the name of mother-of-pearl. In this class are the fresh-water muscles, (the mytilus cyogneus and anatinus of Linné), the haliotis iris (called the ear-shell), the turbo olearus, and several of the trochus tribe, \&c.

The porcelaneous shells, contain a very small portion of soft animal matter; and those of the second class a very large proportion.*

It must be clearly understood, that, all shell-fish are not included in the science of 'Testaceology.t' The crabs,

* See Thomson's system of Chemistry, vol. v. page 507, \&c.

+ Testaceology, is a modern term for the Natural History of ehells, and synonymous with Conchology. 
lobsters, sea-urchins, \&c. are of the crustaceous order.

They differ in their composition from the testacea, the calcareous part of their shell being phosphate of lime, in place of the carbonate of lime.

The crustacea differ from the testacea in a still more striking point of view: it is well known that crabs, lobsters, \&c. cast their shell or covering annually; whereas the testaceous worms retain it as long as they exist. Besides the shells of crustaceous animals, seem to grow all at once; those of testaceous, evidently are made by the animal, gradually adding to them either annually or at least periodically; as may be distinctly seen in the common muscle; and all shells are composed of layers, which is not the case with crabs, \&c. This may be easily proved by taking a shell and filing it slowly, when the different layers are very perceptible; or put a muscle- 
shell into the fire, it will begin to crackle and divide in separate layers. We have numberless instances of shells, both sea and land, which have been broken, and are firmly mended by the animal; and in almost every collection specimens of mended shells may be found.

Shells are only the habitation of soft animals called vermes, or worms, and are the third order of Linnæus's sixth class of animals.

The animals which have been discovered to inhabit shells, are ten:

1. Limax,

2. Doris,

3. Spio,

4. Amphitrite,

5. Terebella,
6. Nereis,

\%. Ascidea,

8. Tethys,

9. Triton,

10. Sepia.

\section{1st. LIMAX.}

Body oblong, creeping, with a fleshy kind of shield above, and a longitudinal flat disk beneath; aperture 
placed on the right side, within the shield; feeler's four, situate above the mouth, and an eye at the tip of each of the largest ones.

This genus is what is generally termed the slug, or snail.

\section{2nd. DORIS.}

Body, creeping, oblong, and flat beneath; mouth placed below, on the fore-part; vent behind, on the back, and surrounded by a fringe; feelers, two and four, seated on the upper part of the body in front, and retractile within their probu receptacles.

\section{3d. SPIO.}

Body projecting from a tube, jointed and furnished with dorsal fibres; peduncles, or feet, rough with bristles and placed towards the back; feelers two, long, simple; eyes two, oblong. 


\section{4th. AMPHITRITE.}

Body projecting from a tube and annulate; peduncles, or feet, small, numerous; feelers two, approximate, feathered; no eyes.

\section{5th. TEREBELLA.}

Body oblong, creeping, naked, often inclosed in a tube, furnished with lateral fascicles, or tufts, and branchiæ ; mouth placed before, furnished with lips without teeth, and protuding a clevate proboscis; feelers numerous, ciliate, capellary, seated round the mouth.

\section{6th. NEREIS.}

Body long, creeping, with numerous lateral peduncles, or feet, on each side; feelers simple, rarely wanting: none; eyes two or four, rarely none.

\section{7th. ASCIDIA.}

Body fixed, roundish, and apparently issuing from a sheath; aper- 
iures two, generally placed near the upper end, one beneath the other.

\section{8th. 'TETHYS.}

Body detached, rather oblong, fleshy without peduncles; mouth with a terminal cylindrical proboscis, under an expanded membrane or lip; apertures two, on the left side of the neck.

\section{9th. TRITON.}

Body oblong; mouth with an involute spiral proboscis; tentacula, or arms, twelve, six on each side, divided nearly to the base, the hind-ones cheliferous.

\section{0th. SEPIA.}

Body fleshy, receiving the breast in a sheath, with a tubular aperture at its base ; arms eight, beset with numerous warts or suckers, and in most species two pedunculated tentacula; head short; eyes large; mouth resembling a Parrot's beak. 
It is upon the exclusive shape of the shell, and not the animal-inhabitant, that the arrangement of Concho$\log y$ is formed.

In early periods, naturalists were in much doubt whether to construct the arrangement from the animal, or the shells; and at last it was determined, for the best of reasons, that it should be the latter. Of the great quantities of shells found, how few have had the animal in them? indeed, there are hundreds we shall never be able to ascertain. The greater part of shells in collections, have been found upon the beach, without the animal in them, which have been cast ashore by the agitation of the sea in storms, \&c.

Most shells are very different in their young and adult state, both in form and colour; the student ought, therefore, to make himself well acquainted with the generic characters, 
to enable him to discriminate the difference. But, indeed, this is often a difficult matter, even to those who have studied the science for many years.

In almost all the cypræa, there is considerable difficulty in distinguishing them from the voluta, in their young state. The denticulated lip being the last part of the shell which the animal forms. The strombus genus want the expanded lip in the young shell, from which circumstance it is frequently taken for the buccinum and murex.

The Linnean arrangement of shells, consists of three orders, viz. Multivalve, Bivalve, and Univalve.

The first order, multivalve, are shells consisting of more parts than two. Every part of a shell which is connected by a cartilage, ligament, hinge, or teeth, is called a valve of such shell.

'The second order, bivalve, are shells 
of two parts or valves, generally connected by a cartilage; for example, the cockle and muscle.

The third order, anivalve, consists of shells complete in one piece; for example, the periwinkle and whelk. This order is subdivided: first, into those with a regular spire, and those without a spire.

The first order consists of three genera: Chiton, Lepas, and Pholas.

The second order consists of twelve genera: Mya, Solen, Tellina, Cardium, Mactra, Donax, Venus, Spondylus, Chama, Arca, Ostrea, Anomia, Mytilus, Pinna.

The third order consists of nineteen genera: Argonauta, Nautilus, Conus, Cypræa, Bulia, Voluta, Buccinum, Strombus, Nurex, Trochus, Turbo, Helix, Nerita, Haliotis, Patella, Dentalium, Serpula, Teredo, and Sabella.

It will now be proper before proceeding to a detail of the Linnean 
grenera, to make the student acquainted with the terms used in Testaceology, as far as regards the diferent parts of shells.

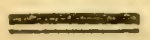 \\ EXPLANATION \\ OF THE

\section{PARTS OF SHELLS.}

\title{
$\longrightarrow$
}

MULTIVALVE.

Operculum is four small valves on the summit of the lepas, which however is in a certain degree stationary; and different from the operculum of univalve shells, which wili hereafter be described. See plate 1st, fig. Ist, A.

Base is that part of the shell by which it is fixed to rocks and other bodies; plate 1st, figures 1 st and $2 \mathrm{~d}$, B B B...-H is a piece of stone to which 
the base is fixed, and $G$ a piece of wood to which the shells of this section are generally affixed.

Liganent is the substance by which the valves or parts of the shell are connected. Some multivalve shells are connected, by the parts of one valve looking into another. Plate 1st, fig. 2d, D D D.

Ridges are those cavities in many of the lepas tribe, sometimes longitudinal and sometimes transverse. Plate 1st, fig. Ist, F F.

Peduncle. A sort of stem by which the shells of the second division of lepas are attached to wood, \&c. It is a kind of membranaceous substance, similar to a bladder but materially thinner, and filled with a liquid which evidently affords nourishment to the animal. Plate 1st, fig. 2d, C C. G a picce of wood to which the peduncle is affixed. 
Feelers are those crenated arms, evolved from the side of the lepas anatifera, and other shells of the second division of lepas. While the animal is in the water it continually moves its feelers, evidently for the purpose of entangling minute marine insects, for food. Plate 1st, fig. 2d, $\mathbb{E} \mathbf{E}$.

\section{BIVALVE.}

Bivalve shells, consist of two parts or valves, connected by a cartilage, and hinge which is generally composed of teeth, those of the one valve looking into a cavity in the other.

The valves of some bivalve shells, are formed exactly alike; and others, are very different; the one of some being smooth, the other rugose; one flat, and another convex; and often one is shorter than the other.

The shells of the mya, solen, tellina, venus, \&c. have in general both valves alike, while those of the spondylus, 
ostrea, anomia, and pinna, have in general dissimilar valves. The first of these kinds are called equivalve, and the latter inequivalve.

Equilateral shells are those whose sides are alike, as in the shells of ostrea, commonly termed scallopshells in England, or those shells worn by pilgrims in former times ;

"Aud fix'd the scallop on his hat before."

PARNELI.

This is also exemplified in the Arca Glycimeris and Pilosa of Linnæus.

Inequilateralvalves are shells whose sides are unequal ; and are of different shapes, as in the mactra, donax, \&c.

Summit is the most elevated point of that part of the shell in which the hinge is placed; plate 1st, fig. $4 \& 8$, - $\boldsymbol{a} \boldsymbol{a}$.

In naming this the summit, we do not follow the axiom of Linnæus, but that of a modern author whose autho- 
rity we value; and because we consider it more properly the summit of the shell, than the opposite extremity.

Base, is the reverse of the above, or that part of the shell immediately opposite the summit. Plate 1st, figrs. 6 th and 7 th, $d d$.

Sides, the right and left parts of the valves; plate Ist, fig. 6 th, $c$.

Anterior slope, is that part of the shell in which the ligament is situated. in viewing the anterior slope in front, the beaks of the shell retire from view. Plate 1st, fig. 4 th, $i$.

Posterior slope, that part of the shell opposite the anterior slope; in viewing it in front, the beaks point to you. Plate 1st, fig. 4th, $k$.

Disk, the convex centre of a valve, or most prominent part of the valve, suppose it with its inside lying undermost. Plate Ist, fig. 4th, 0.

Inside, the concave part of a valve. Plate 4th, fig. 6th, $n$. 
Cicatrix, or Tongue, is the impression left on the inside of the valves, by the adhering muscles of the animal. It differs in most shells, according to the shape of the muscle, and is either semi-ovate, round, lunate, elongated, Sc. It is often of great use in distinguishing a species; being, with a very few exceptions, alike in shells of the same species. Some shells have only one cicatrix, as the edible oyster, and muscle; others have two, and some few more ; the Tellina Fusta for example. Plate 1st, figures 6 and $8, e$ e e e.

Lunule. The lunated depressions, situated in the anterior and posterior slopes. In different species of the Venus they are prominent, characteristic marks, often of much service in ascertaining a species. Plate 1st, fig. 4th, $b$ b.

ligament perforation. The circular aperture, or perforation, through which the ligament passes; by which 
the animal of the anomia attaches itself to stones, and other marine extraneous bodies; it is in general situated in the flat valve, though there are a few exceptions to the contrary. Plate 1st, fig. 7 th, $m$.

Hinge, is the point by which bivalve shell are united, it is formed by the teeth of the one valve inserting themselves between those of the other, or by the teeth of one valve fitting into the cavities or sockets of the opposite valve.

It is on the peculiar construction of the hinge that the generic character of Bivalve shells is principally founded, together with the general contour of the shell. Plate 2nd, figures 1st and $3 \mathrm{~d}, q q q$.

Teeth of the Hinge. Upon the number and relative situation of the ieeth, principally depend the specific distinctions; they are of various forms, and very differently placed; 
some are single and large, others numerous and small, orbicular, spatuliform, laminated, \&c. Some hinges have no visible teeth, and are termed inarticulate; those with few teeth are termed articulate; and those with many teeth multiarticulate.t. Plate 1 st, figures 6 th and 8 th, $g \boldsymbol{g} g \boldsymbol{g}$. Primary Teeth, are those teeth in general about the centre of the hinge, and are for the most part broad, large, and distinct, and often elevated; and in general are inserted in a cavity in the opposite valve. They however differ very much in some shells, but may easily be distinguished. Plate 4 th, figures 1st, $3 \mathrm{~d}$ and $7 \mathrm{th}$, a $a$ a $a$ a.

Lateral Teeth, $\S$ are teeth which diverge from the umbo, and are in general long and flat, often double, and divided by a groove or hollow. Plate

* When a primary tooth has a groove or bollow in its cen. tre, it is called complicated. Plate 4 th, fig. 6 th, $e$.

+ Plate 4 th, figures 1 st and 12 th. $\ddagger$ Plate 4 th, figures $2 n d$, Sd, 4 th, \&ce $\quad$ Plate 4 th, fig. 10th. 
4 th, figures 2 nd, 4th, 6 th and 7 th, $b \vec{b} b$.

Double Teeth, plate 4th, fig. 1st, $c c$. Incurved Teeth are those which are bent round, as in the single tooth of the Solen Siliqua. Plate 4th, fig. $8 \mathrm{th}$, $f f$.

Middle Teeth. Plate 4th, fig. 4th. $d d$.

Numerous Tecth, are those small teeth, of which the hinges of all the Arca are formed, set in rows. Plate 4 th, fig. 10th, kl k.

Cavity of the Flinge. The hollow depression in which the ligament of the Ostrea is situated, generally of a 1riangular form. Plate 4 th, fig. $11 \mathrm{th}, g$.

Ligament of the Hinge, or cartilage, is that flexible fibrous substance by which the valves are united, and the hinges kept in their proper plars; always situated near the beak. e 2nd, figures 1st, $3 \mathrm{~d}$ and 4 ih, $l \cdot l$; plate 4 th, fig. $3 \mathrm{~d}, n$. 
Beak is the extreme point of the summit of bivalves, which for the most part points downwards, or to the one side, as in most species of Venus, \&c. Plate 2nd, fig. 5th, $r \boldsymbol{r}$.

Scam. When the valves are closed, the line between them is so called. Plate 2nd, fig. 6 th, $t \boldsymbol{t}$.

Umbo. That place situated immediately under the beak. Plate 1st, fig. $6 \mathrm{th}, w$; and plate $2 \mathrm{nd}$, fig. 4 th, $w$.

Ears. Two processes on each side of the beak, in most of that division of Ostrea, called scallops; some have one ear very large, and the other small; and some are scarcely observable on one side. Plate 2nd, fig. 2nd, $h$ h.

Superior Ear. Plate 4th, fig. 11th, $h$. Inferior Ear. Do. do. i. Margin, or Limb. The extreme edge of the whole shell, or either valve, all round. Plate 1 st, fig. 4 th, $p$; and plate 2nd, fig. 1st, $p$. 
Crenulated margin. That fine sawlike edge of most of the cockles, which unite into the notch in the opposite valve. It is by no means uncommion in other shells, particularly the Donax. Plate 4th, fig. 6th, $m$ m.

Strice are fine thread-like lines, generally on the exterior surface of shells, and is sometimes both longitudinal and transverse, and likewise oblique. In some instances the insides of shells are striated; for example, the Murex Tulipa. It is often of much use in distinguishing species. Plate 2nd, fig. 2nd, $f$.

Right Valve is that valve which, when viewed with the inside towards you, the anterior slope points to your right hand. Plate 1st, fig. 8th; and plate 4 th, figures 5 th and 6 th, $B$.

Left Valve. The opposite of the above; the anterior slope points to the left hand, when viewed from the 
inside. Plate 4 th, figures $3 \mathrm{~d}, 6 \mathrm{th}, 7 \mathrm{th}$, 9th, \&c.

Length of the Shell is taken from the ligament, or the beak, to the opposite margin. Plate 1st, fig. 5th ; and plate $\mathbf{2 n d}$, fig. 4 th, $\boldsymbol{u} \boldsymbol{u} u \boldsymbol{u}$.

Breadth is measured from the most extreme edge of the anterior and posterior slopes, being in a contrary direction from its length. Many shells are broader than long, such as most of the Myæ, Solina, Tellina, \&c.; and the Mytilus, Ostrea, Pinna, \&c. are in general longer than broad. Plate Ist, fig. 5th ; plate 2nd, fig. 4 th, $v v v v$.

Byssus, or beard, is an appendage composed of filaments of a silky texture, by which some of the Bivalves fasten themselves to their beds, such as the muscle. Plate 2 nd, fig. 6 th, $s$.

UNIVALVE.

The shells composing this order, are far more numerous than the two 
preceding, both in genera and species; and it requires a considerable degree of attention, to discriminate many of the species, as they run into each other so much; and of many of the species there are several varieties.

It is by the general outline that the shells of this order are distinguished, together with the formation of the spire, and aperture; from their having a canal or gutter, the pillar-lip, and the outer-lip being expanded, together with the notches, \&c. on the outer surface; the colours also, are of service in describing species, though it cannot in all cases be depended on, many of them being subject to great variety.

Linnæus divides his Order Univalve into two sections, turbinated shells within a regular spire, and those without any regular spire.

Apex. The summit or highest part of the spire. Plate 2 nd, $\boldsymbol{A} \boldsymbol{A} \boldsymbol{A}$. 
Base is the opposite extremity fromi the apex, or tip of the spire. In shells with a beak or rostrum, it implies the tip of such beak; plate 2nd, fig. 11 th, $\boldsymbol{B}$. In shells without a beak, it is understood to be the lower part, as before-mentioned, opposite the apex; plate 2nd, figures 8 th and 9 th, $\boldsymbol{B} \boldsymbol{B}$. In the patella dentalium and teredo, and some others, the base of the shell is that part on which it rests when it is laid on its mouth.

Body of the shell. The first or lower whorl of the spire, which is, in general, longer than the remaining whorls; and often, the difference is much greater. Plate 2nd, figures 10th and 12 th, $\boldsymbol{F} \boldsymbol{F}$; and plate $3 \mathrm{~d}$, figures 7 th and 9 th, $\boldsymbol{F} \boldsymbol{F}$.

Front of the shell, is when the aperture faces the observer. Plate $2 \mathrm{nd}$, fig. $7 \mathrm{th}, I$; and plate $3 \mathrm{~d}$, fig. $8 \mathrm{th}, I$.

Back is when the aperture is turned 
directly from the observer. Plate 3d, figures 5 th and 10 th, $G \boldsymbol{G}$.

The venter, or belly, is the most prominent part of the lower whorl or body, and generally situated in the vicinity of the lip; and formed by the convexity of the aperture. It is in general only made use of in describing shells, whose body is large in proportion to the spire. Plate 3d, figures 5 th and 10 th, $\boldsymbol{H} \boldsymbol{H}$.

Sides. The extreme edges of the shell, either viewed from the front or back. Plate 2nd,fig. 11 th, $k k k k k k k k$.*

Aperture, or mouth, is that part of the lower whorl, by which the animal protudes itself. This is one of the principal generic distinctions of Univalve shells, and differs very much in shape; some apertures being rounded, others semilunar, angular, \&c. Plate 2nd, figures 9 th and $11 \mathrm{th}, C C$; and

* Right side is when the shell is viewed in front, that side next the observer's left hand, Left side, the side with the aperture in it. 
plate $3 \mathrm{~d}$, figures 1 st, $3 \mathrm{~d}$ and $14 \mathrm{th}$, CCC.

Canal, or gutter, is a continuation of the aperture, of those shells with $\mathrm{a}$ beak, in which it forms a concave gutter, running from its commencement in the aperture, to the extremity. Plate 2nd, figures 10th and 11th, $Q Q$; plate $3 \mathrm{~d}$, fig. $8 \mathrm{th}, \boldsymbol{Q}$.

Beak, or rostrum, is that lengthened process in which the canal is situate; it commences a little higher up, on the outside, than the insertion of the canal in the inside, which is always distinctly marked by the line of the aperture. Plate 2nd, fig. 11th, $P$.

Pillar, or columella, is that process which runs through the centre of the shell in the inside, from the base to the apex in 'most univalve shells, and appears to be the support of the spire ; and, indeed, seems to form that part of the shell; it is in general grooved or folded, and various other shapes; 
but, as it is situated in the interior of the shell, a minute description is unnecessary. Plate 2nd, figures 10th and 12th, $\boldsymbol{M} M \boldsymbol{M} M \boldsymbol{M}$; and plate 3d, fig. 9th, $\boldsymbol{M} \boldsymbol{M} \boldsymbol{M}$.

Pillar Lip is a continuation of the glossy process with which the aperture is lined, expanded on the columella. Plate $3 d$, figures 7 th and 8 th, 00 .

Outer Lip. The expansion, or continuation of the body of the shell, on the left margin of the aperture, and is also lined with the glossy process of the aperture. Plate 2nd, fig. 7 th, $N$; and plate 3d, fig. 8th, $N \boldsymbol{N}$. The latter is an example of the alated or winged shells.

Plaited Columella are those folds, or plaits, which are the distinguishing characteristic of the Voluta genus. Plate 2nd, fig. 7th, z.

Operculum, or lid. This is only an appendage to the turbinated or spiral 
shells, affixed to the animal, sometimes of a testaceous, in others a cartilaginous substance. It is only calculated for the protection of the animal, when it retires within its dwell. ing, of which it may be termed its door, and is adapted to the shape of the aperture, which it closes nicely up. Every one must have observed the cartilaginous operculum of the common periwinkle, (the Turbo Litto ratus of Linné,) which has a brown horny appearance, and must in general be removed, before the animal can be taken out when boiled. Plate 3d, fig. 4 th.

Spire is all the whorls of the shell, except the lower one, which, as before observed, is termed the body of the shell. Plate 2nd, fig. 12th, D; and plate $3 d$, figures 7 th and 8 th, $D D$.

The spire is a prominent feature of the Univalve ; and upon its being elerated, depressed, \&c: depends much 
of the generic and specific definition. Adamson in his 'Natural History of Senegal,' printed at Paris, in 1757, says that the external character of the spire, varies according to the plane they turn upon, which, he observes, is either horizontal, cylindrical, conic or ovoid. At the same time, he admits that there are a great many intermediate forms, which cannot properly be defined.

It is a remarkable circumstance, that many of the young shells, have not the same number of wreaths as the adults; from which circumstance it would appear, that the part of the animal nearest the apex, never increases in size. The number of wreaths cannot, at all times, be depended upon.

Whorl is one of the wreaths or volutions of the shell. Plate 2nd, fig. 8th, $L$; and plate $3 \mathrm{~d}$, fig. 10th, $L$.

Depressed Spire is when the spire 
is very flat. Plate 2 nd, fig. 12 th, $D$; and plate $3 \mathrm{~d}$, fig. 5 th, $\mathbf{S}$.

Involuted Spire, those shells which have their whorls, or wreaths, concealed in the inside of the first whorl or body, as in some of the Nautilus and Cyprac. Plate $3 \mathrm{~d}$, fig. $3 \mathrm{~d}, \boldsymbol{T}$; plate 7 th, fig. 19th; and plate 8 th, fig. 21.

Suture of the Spire, or whorls, is a fine spiral line, which separates the wreaths or whorls; it is sometimes crenulated, in others sulcated, \&c.

Reversed, or Heterostrophe Spire. As Mr. Montagu's definition of a reversed shell is very distinct, and easily understood, I shall here extract it. "Every Conchologist knows, that most convoluted shells turn one way, and that there are few species which are heteroclitical, or invariably turn contrary to the usual manner. Some indeed have doubted, whether this is a permanent character; there 
requires, however, no argument to prove it is so, to those who have taken the trouble to examine the common species of heterostrophe shells, which daily present themselves to our notice in our rural walks. Indeed, it is rather strange that no one of these shells, whose nature is to have their spires turn in the more unusual manner, has (to our knowledge) even been met with to vary from that formation; as such accidental deformities have been found, in a few instances, amongst those which are usually termed dexterals, of have the more usual spiral turns, and have become lusis heterostrophon shells.

" In order, therefore, to explain which way the turn of the spiral convolutions of a reversed shell takes, omitting the vague siguification of turning to the right or left, we shall observe, that the more common turn of shells is with the apparent motion 
of the sun, or as the index or hand of a clock moves.

"But in order to be more clearly understood, let us compare the spiral volutions of a shell to a common corkscrew, and we shall find that whether the mouth, or apex, is placed upwards, the spires will turn from the upper to the lower end like a common screw, which is in the same direction as the index of a timepiece, and what is commonly understood by a dextral or right-handed screw. As a further definition, such shells have their aperture on the right side, when examined with that end downward; and is in the direction of the sun's apparent motion.*

* That different authors have described both sides of the shell as the right, is very clear; but it appears to me, $\mathbf{M r}$. Montagu has himself run into a mistake, concerning the right and left sides of the shell; and I have termed that side of the shell with the aperture in it, when viewed in front, the left side; contrary to Mr. Montagu. It is admitted by most Conchologists, that the apex or tip of the spire, is the top of the shell, and the lower region, in which the aperture is situate, is the 
"On the contrary, a reversed shell when laced in a perpendicular position, has its spiral volutions in an opposite direction to the motion of the index of a watch, or a clock, or to a common screw; and, in fact, resembles what is usually termed a siuistral, or left-handed screw. These have their aperture on the left side, or opposite the left hand of the person, holding the shell with the mouth downward; and the opening is opposite the sun's apparent motion. Plate 3d, fig. 13th.

base or bottom. It is also admitted, that when the shell is placed on its base, with the aperture facing the observer, that this is termed the front-plate $3 d$, figures 7 th and 3 th, \&c.; and that placed with the aperture from the observer, it is called the back-plate $3 \mathrm{~d}$, fignres 9 th and 10 th. When all this is adnitted, it appears to me that the side in which the aperture is situated, is unequivocally the left sidc, and the opposite extreme the right. Surely if a man is placed on his feet, with another facing him, the one could not call the side fronting bis right side, the right side of him opposite. If any thing, whatever it may be, has a top, base, and proper front, it must also have a proper right and left side; and what I lave de. acribed as such, I think will be found to be so. 
"In order to determine whether a flat shell, whose volutions are laterally placed, is a reversed species, we have only to examine which way the volutions turn from the apex, or the centre, towards the mouth; and if we find it contrary to the motion of the index of a watch, it is a heterostrophe, or reversed shell ; and vice versa."

A flat shell is figured in plate $3 \mathrm{~d}$, fig. 14th.

"In some of the more depressed species of llelix, or Nautilus, attention is requisite to be paid to the mouth, in order to determine which is really the upper side of the shell, for it is on that side the spiral turns are to be taken from the centre or apex; and, in most instances, this is to be determined by the oblique direction of the aperture to the under part, where the lip rarely extends so far as on the upper part. In fixed shells, such as Serpula, there is no difficulty, 
aks the side which is sessile must be considered as the base, or under part. Thus in the Serpula Lucidu the fixed part is sometimes very small, and the mouth protends spirally upwards, in a contrary direction to the sun; and therefore must be considered a reversed on heterostrophe shell, the same as if the volutions nearest the mouth had turned laterally upon the centre or fixed ones. 'This shell, indeed, is most frequently found with regular lateral volutions; and though subject to great variety, with respect to contortions, it invariably turns the aperture one way.

"In some species of Nautilus, however, there can be no rule to ascertain whether it is dextral or sinistral ; for when the aperture is exactly lateral, the lip collapses the body equally, and the sides of the shell similar, as in the Natilus Calcar, it cannot be defined. In others of that genus, as in $\mathbb{N}$. 
carii and Beccavii perversus, two shells, the principal distinction of which, is the contrary turn of their volutions, it is easily determined, by the convexity of the upper site; and of course, the aperture being placed somewhat beneath." Testacea Britannica, page 352, \&c.

Chambers are the divisions formed by partitions, at regular intervals; as in the Nautilus. Plate 3d, fig. 11th, WWWWW.

In some of the Serpula there are nlso divisions, but they are not regular as the preceding; and they differ from the Nautilus, in wanting a Siphunculus or communication between the chambers; the animal forms a complete partition and adds to its shell, which it would appear to be necessitated to do, from its body growing too large for its abode.

Several of the Patella genus, have chambers of a laminiform, subspiral, 
or other form. Plate $3 d$, fig. $6 \mathrm{ih}$, W

Unbiricus is in greneral e circular perforation, in the base of the lowe: whorl, or bodz, of many univalves; and common to most of the Troclie, in some of which it runs from the base to the apex; widest at the base, and gradually tapering to the top. Plate 3d, fig. Ist, $U$.

Sub-zmbilicated shells, are those which have the umbilicus covered in a greater or less degree by a thin process; which, in some, almost entirely closes the opening or mouth.

Shells which have no umbilicus are termed imperforate.

Siphunculus is that small round perforation which forms a communication between the chambers of the Nautili, which runs through the whole spire of the shell. Plate $3 \mathrm{~d}$, fig. 11th, V.

Ribs are those longitudinal protuberances which are in many of the 
univalve shells. Plate $3 \mathrm{~d}$, fig. 12th, $\boldsymbol{R} \mathbb{R} \boldsymbol{R}$.

Teeth of univalves, according to Mr. Montagu, are not properly denticles, or tooth-sbape protuberances, but are fine white lamina, or ridges, running spirally backwards, in a parallel direction to each other; those on the exterior lip may, in most instances, be traced through the outside of the shell, and are nearly alike in length. Plate 3d, fig. 13ih, $\boldsymbol{a}$.

Eipdermis is a skin, or cuticle, with which the exterior surface of many of the univalve and bivalve shells are covered; and it is destined by nature to protect the surface of their shells from being injured. It is membranaceous, or similar to the periosteum, which covers the bones of animals. This skin seems to be formed entirely by the animal, and is uniformly obserred in some species, and not at all in others: but those shells with a 
rugged surface have almost always this epidermis. In some it is laminated, velvety, fibrous or rough, and in others very thin and pellucid, and admits the colours of the shell to shine through it. Although many shells are very beautiful, even with this cuticle on them, they are much more so when it is removed; but I would by no means advise the collector of shells to remove it, unless he may have several specimens of the same shell; and then he may do it by way of variety; but it is always preferable to keep them in a state of nature.

All other protuberances, furrows, \&c. will be described at the end of the work, in the Glossary of Terms used in the Science.

A shell with epidermis is represented in plate $3 \mathrm{~d}, \mathbf{W}$; and the effect of the epidermis removed at $I$. 
The next thing to be taken into consideration, is the genera composing the three orders of shells.

\section{ב \\ $\mathbb{O} \mathbb{F} \mathbb{G} \mathbb{E} \mathbb{E} \mathbb{R} \mathscr{A}$. \\ ${ }_{0 \rightarrow \infty}$ \\ ORDER FIRST.}

MULTIVALVE SHELLS.

Animals soft, of a simple structure, and covered with a calcareous habitation or shell.

Genus 1st.--CHITON. Animal inhabiting the shell a Doris; shell consisting of several segments or valves, placed transversely on the back of the animal, and lying upon each other at their anterior edge. Linnæan Syst. No. 300 . 
The animals of this genus adhere to rocks and stones, in general near low water mark, and are, at first view, very like an oniscus. Plate 5th, fig. 1 st.

Ilabitation. The Chitons have only been found to inhabit the ocean.

In Turton's Linné 28 species of Chitons are described. Seven species have been discovered in the British seas.

Genus 2nd.---LEPAS. Animal a Triton; shell affixed at the base, and consisting of many unequal erect valves. Kimn. Syst. No.301.

The Lepas are termed acorn shells in England. This genus consists of two families or divisions, very different in their form. The first of which is the balani, or acorn shells, of a subconic form, with an operculum or lid, consisting of either four or six valves. The body of the shell has six valves. Plate 5th, fig. 2nd; and plate 1st, fig. 
1st. The second family is the anatiferous, or goose-bearing shells, as they are called, which is connected to, and supported at the base by a tendinous tube or pedicle, which being of a flexible nature, allows the animal to writhe about in quest of food ; it has no operculum, is wedge-shaped, and consists of fire or more unequal valves. Plate 1st, fig. 2nd.

Mr. Montagu in his Testacea Britannica, made those two families into two distinct genera. It is singular Linné should have arranged shells so very dissimilar in the same genus.

Habitation. The Lepas have only been found to inhabit the ocean.

The shells of this genus adhere in clusters to rocks, shells, floating wood, and other extraneous substances, and being incapable of changing place, are supposed to be true hermaphrodites.

In Turton's Linné thirty-two spe- 
cies of this genus are described; fifteen species have been discovered in the British seas.

Genus 3d..-PHOLAS. Animal an Ascidea; shell bivalve, divaricate, with several lcsser, differently shaped, accessory ones, at the hinge; hinges recurved, united by a carlilage; in the inside, beneath the linge, is an incurved tooth. Linn. Syst. 302. Plate 5th, fig. $3 d$.

Mabitation. Pholades are found below high water-mark, burrowed in hard clay, lime-stone, or sometimes free-stone, and also wood, which they perforate in their younger state, and as they increase in size enlarge their habitation.

The phosphorescent properties of the Pholades are very remarkable; it contains a liquor which shines with uncommon splendour in the dark, and illuminates whatever it touches, or happens to fall upon. See Memoirs of the French Academy, 1712. 
"There is a remarkable shell-fish called Pholes, which forms for itself holes in different kinds of stone. This fish illuminates the mouth of the person who eats it ; and it is remarked, that contrary to the nature of other fish, which give light when they tend to putrescence, this is more luminous the fresher it is; and when dried, its light will revive on being moistened either with salt waier or fresh ; brandy however immediately extinguishes it." Priestly's Optics, page 56\%.

It is to be regretted, that the experiments made by chemists on those animals, which have a luminous appearance in the dark, have not been sufficiently decisive, to enable us to state the true cause of it; but it undoubtedly proceeds from phosphorus, which is abundant in all animal bodies.

In Turton's Linné twelve species are described; five have been found to inhabit the British coasis. 
OF CONCHOLOGT.

\section{ORDER SECOND.}

BIVALVE SHELLS.

Genus Ath.--MYA. Animal an Ascidia; shell bivalve, generally gaping at one end; hinge with broad, thick, strong, patulous tooth, seldom more than one, and not inserted in the opposite valve. Liman. Syst. 303. Plate 5th, fig. 4th.

Habitation. The Myre are to be found both in the sea and in rivers. The marine kinds generally live under sand or sludge, and the place where they lie is betrayed by a small hole, out of which they occasionally protude their proboscis. Those which inhabit rivers, are generally found in the mud at its bottom. In some places the animals are used for food; but what makes them of considerable import. 
ance is, the quantity of pearls which they sometimes produce. We are told by Camden, for the value of the pearls produced by the Mya Margratifera, that Sir John Hawkins had a patent for fishing for that shell in the river Irt in Cumberland.

'The French naturalists divide this genus into three distinct genera: Mya, Glycimeris, and Vulsella.

In Turton's Linné twenty-six species are described; and fourteen have been ascertained to inhabit Great Britain.

Genus 5th.-.. SOLEN. Animal an Ascidia ; shell bivalve, oblong, open at both ends; hinge with a subulate reflected tooth, often double, and not inserted in the opposite valve. Linn. Syst. 304. Plate 5th, fig.5th. Razor shell.

Ilabitation. The Solens have only been found to inhabit the ocean ; they are generally found, buried about six inches deep, in the sand; their resi- 
dence is known by a small dimple on the surface. In some places they are used as food.

The French naturalists have divided the Solens into three distinct genera: Solen, Sanguinalaria, and Corbula.

In Turton's Linné twenty-three species are described; eleven species have been ascertained as British.

Genus 6th.--TELLINA. Animal a Tethys; shell bivalve, generally sloping on one side; in the fore-part of one valve a convex, of the other a concave fold; hinge with usually three teeth, the lateral ones smooth on one side. Limu. Syst. 305̆. Plate 5th, fig. 6 th.

There are three families of the Tellinæ: ovate and thickish,* ovate and

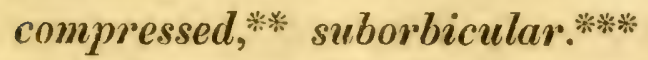

Habitation. The Tellinge are found to inhabit the ocean, rivers and lakes. Those of the ocean lie buried in the sludge, near the shore, and make two H 
apertures in the sand; when the tide has receded, they may be easily found by looking for these marks.

The French writers have divided the Tellina into three genera: 'Tellina, Cyclus, and Pandora.

In 'Turton's Linné ninety-four species are described: twenty-two species have been discovered in Britain.

Genus "th.--CARDIUM,(acockle.) Amimal a'Tethys; shell bivalve, nearly equilateral, equivalve, generally conrex, longitudinally ribbed, striate or groored, the margin dentated; hinge with two alternate teeth in the middle, near the beak; one of them commonly incurved; and larger remote lateral teeth on one side, each looking into the opposite. Linn. Syst. 306. Plate 5th, fig. 7th.

Ilabitation. The Cardium, with the exception of one species, have only been found to inhabit the ocean; this species, the Cardium Fluviatile, has 


\section{OF CONCHOLOGY.}

been found, sparingly, at the mouth of the Tees in Yorkshire. Cockles, in general, live just under the surface of the sand, barely covered; they are necessitated to be near the surface, from the shortness of their tube, by which they draw in and throw out the water.

The French have divided the Cardium into three genera: Cardium, Bucarde, and Cordiformes.

In 'Turton's Linné fifty-two species are described; fifteen species have been found in Great Britain.

Genus 8th.---MACTRA. Animal a Tethys; shell bivalve, with unequal sides, equivalve; middle tooth of the hinge complicated, with a small hollow on each side, lateral teeth, remote, and inserted into each other. Linn. Syst. 307. Plate 6th, fig. 8th.

Habitation. Shells of this genus have only been found to inhabit the ocean. These shells lurk in the sand 
or sludge, most commonly at the mouths of rivers, or near them.

The French naturalists divide the Mactra into two genera: Mactra and Lutraria.

In Turton's Linné twenty-seven species are described; twelve have been discovered in the British seas.

Genus 9th.--DONAX. Animal a 'Tethys; shell bivalve, with generally a crenulate margin, the frontal margin very obtuse; hinge with two teeth, and a single marginal one placed a little behind, rarely double, triple or none. Linn. Syst. 308. Plate 6th, fig. 9 th.

The shells of this genus are in general triangular, inequilateral, flattened, treuncated before, and wedgeshaped.

Habitation. The Donax has only been found to inhabit the ocean; lurking in the sand of the shore, and 
may be found on the reflux of the tide.

In Turton's Linné nineteen of this genus are described; and six species have been found in the British seas.

The French conchologists have divided this genus into two: Donax and Petricola.

Genus 10th.--VENUS. Animat a Tethys; shell bivalve, the frontal margin flattened, with incumbent lips; hinge with three teeth, all of them approximate, the lateral ones divergent at the tip. Linn. Syst. 309. Plate 6th, fig. 10th.

'This genus is divided into two sections: pubentes* and impuberes.*** This latter section is divided into three families: subcordata, $\lceil$ orbiculata,,+ and ovalis. $y^{\prime}+{ }^{\circ}$

Dr. Turton has not followed Linné in the above arrangement, but has divided them into three sections; $\mathbf{A}$ somewhat heart-shaped, B orbicular, 
Coval, a little angular near the beaks. Ifabitation. The shells of this genus have only been found to inhabit the ocean. They in general lurk in the sand; and many of the larger species are only to be found in very deep water.

The shells composing this numerous tribe, are perhaps the most elegrant, and beautifully diversified, of all the bivalve shells.

In Turton's Linné, no less than 154 species are described; and 25 species have been discovered to inhabit the seas around Great Britain.

Genus 11th.--SPONDYUUS. Animanl a Tethys: shell hard, solid, and ridged, with unequal valves; one valve in general convex, and the other rather flat: hinge with two recurved teeth, separated by a small hollow. Limn. Syst. 310. Plate 6th, fig. 11 th.

Mabitation. This genus has only been found to inhabit the ocean. They 
adhere to rocks in deep water, and require considerable force to tear them from their retreats.

Some of the Spondyli have ears, and others not; they are in general strong, rugose shells. 'This genus requires considerable attention, as some of the species vary exceedingly, so much so that many have been taken for distinct species.

The French writers divide the Spondyli into two genera: Spondylus, and Plicatula. The valves of the last are in general rude, thick, uneven, and uncouth.

In Turton's Linné only four species are described; no species of this genus have been found to inhabit the British seas.

Grenus 12th.--CHAMA. Animal a 'Tethys; shell bivalve, rather coarse: hinge with a callous gibbosity, obliquely inserted into an oblique cavits: 
anterior slope closed. Tinn. Syst. 311. Plate 6th, fig. 12th.

Habitation. The shells of this genus have only been found to inhabit the ocean; they live only in very deep water.

The Chama Gigas is the largest and heaviest shell yet discovered, being sometimes of the amazing weight of 532 pounds, and the animal inhabitant so large as to furnish one hundred and twenty-two men with a meal : and is said to be very palatable: and such is its strength that it is able to cut asunder a ship's cable. 'This species inhabits the Indian Ocean.

The French writers divide this genus into five, Chama, Tridacna, Hippossus, Cardita, and Isocardia.

In Turton's Linné twenty-five species are described. Only one of this genus has been found in the British seas, the Chama Cor, discovered by Captain Laskey, off St. Abb's-head in 
Scotland. To that gentleman the British Conchologist is indebted for the discovery of inany new species.

Genus 13th.---ARCA. Animal a Tethys; shell bivalve, equivalve; hinge with numerous sharp teeth, alternately inserted between each other. Limn. Syst. 312. Plate 6th, fig. 13th.

Linné divides this genus into two families: *with the margin entire; **with margin crenulated; and has subdivided each into two sections, theaks recurved; and thbeaks inflected.

Mabitation. Some of the Arca are affixed by the foot of the animal to rocks; and others lurk in the sand or mud near the shore, generally between high and low water mark.

The Arca have only been found to inhabit the ocean.

This genus takes its name from the strong resemblance the Arca Noce, and some others, have to the hull of a 
vessel when the valves are united. Many of the Arks are, however, void of this character, but are sufficiently. united to the genus, by the number and construction of their teeth.

The French Conchologists have marle two genera of the Arca: Arca and Nuclia. The Arca Nox is an example of the former, and the Arca Nucleus of the latter.

In Turton's Linné forty-two species are described; and six species have been found on the British shores.

Genus 14 th..-OSTREA, (or oyster.) Animal a Tethys : shell bivalve, generally with unequal valves, and slightly eared; hinge without teeth, but furnished with an ovate hollow, and mostly lateral transverse grooves. Linn. Syst. 313. Plate 7th, fig. 14th.

The Ostrea is divided into three families: *valves radiated and eared, as in scallops; ***rugged or rough, as in the oyster; **** hinge with a perpen- 
dicular furrowed line, as in the species of Perna. The first family is again subdivided into three sections: fralves aequilateral, and ears equal; ttears unequal, and having one of them generally ciliated with spires within; t+fralres gibbous on one side.

Habitation. The Ostrea have only been found in the ocean; some lurk in the sand in large beds, others adhere to rocks, and some to trees on the shores of the West Indies, \&c.

The Ostrea might with great propriety be divided into two species, scallops and oysters, as those sections are very dissimilar.

The French Naturalists have formed this genus into seven: Ostrea, Pecten, Malleus, Perna, Lima, Pedum, and Gryphus.

In 'Turton's Linné 137 species are described; nine species are found in the British seas. 
Most of the foreign, and a few of the British Pectens, are very beautiful shells.

Genus 15th.--ANOMIA. Animal an emarginate ciliate strap-shaped body, with bristles or fringe affixed to the upper-valve; arms two, linear longer than the body, connivent projecting, alternate on the valve and ciliate on each side, the fringe affixed to each valve; shell bivalve, inequivalve, one of the valves flattish, the other gibbous at the base with a produced beak, generally curved over the hinge; one of the valves often perforated near the base; hinge with a linear prominent cicatrix and a lateral tooth placed within, but in the flat valve on the very margin; two bony rays for the base of the animal. Linn. Syst. 314. Plate 7th, fig. 15th.

Habitation. The Anomia have only been found to inhabit the ocean. The animal attaches itself to fuci, 
shells, stones, and other extraneous bodies at the bottom of the sea: they are generally affixed by a ligament which passes through the perforation in the flat valve. A species called the Squamula is often found adhering to the Pecten Opercularis, and is very common at Aberlady Bay in Scotland; it resembles the scale of a fish, and partakes of the form of the furrows and strize of the Ostrea, which makes it very beautiful.

Lamarck has divided the Anomia into three genera: Anomia, Calceola, and Crania.

The Anomia Sandalium of Linné, is an example of the Calceola, and the Anomia Craniolaris of the Crania.

In Turton's Linné fifty-one species are described; and six have been discovered on the British shores.

Genus 16ih.---MVTLUS, (or muscle.) Animal allied to an Ascidia; shell bivalve, rough, generally afixed 
by a byssus or beard of silky filaments ; hinge mostly without teeth, wih generally a subulate, excavated, longitudinal line. Linn. Syst. 315. Plate 7th, fig. 16th.

The Linnean Mytili are divided into three families: * Parasitici, \&c. parasitical, affixed as it were by claws, as exemplified in the Mytilus Cristi Galli; * Plani, \&c. flat or compressed into a flattened form, and slightly eared; as in the Mytilus Margratiferus ; *** Ventricosiusculi, \&c. ventricose or convex, as in Mytilus Edulis.

Mabitation. The Mytili are found to inhabit the ocean, lakes, rivers and ponds. Marine Muscles adhere to rocks or beds by a thin byssus, and some to the Gorgoniæ by claws. Some penetrate calcareous rocks, \&c. where they reside without changing place, some of them adhere to rocks on the shore, and are either used for bait or food, and as such they are esteemed 
by many; but it is dangerous to eat plentifully of them, unless they are known to be wholesome, as many of them produce very bad effects after they are taken into the stomach. The fresh water muscles are generally found on the surface, or a little way under the mud. Some muscles produce pearls.

Lamarck divides this genus into three species: Mytilus, Modiolus, and Anodonta.

In Turton's Linné sixty-four species are described; and thirteen have been found to inbabit the seas, lakes, \&c. of Great Britain.

Genus 17th.--PINNA. Animal a Linax; shell sub-bivalve, fragil, upright, gaping at one end, and furnished with a byssus or beard: hinge without teeth, the valves united into one. Linn. Syst. 316. Plate 7th, fig. 17 th. 
Habitation. The Pinnæ, which frequently grow to a large size, are only found to inhabit the ocean. They are generally found standing erect in the smoother water bays, with the broad end or base of the shell uppermost. And they are sometimes found affixed by their byssus to rocks.

In Italy the byssus of the Pinna is woven into a sort of silk. The fibres or filaments of which it is composed, are very tough, and of a fine glossy brown colour. The ancient Romans highly esteemed articles made of this byssus; and at Naples and Palermo there are still manufactories of it.

This genus forms an excellent intermediate link between the bivalve and univalve shells, being in truth what Linné defines it---a sub-bivalve shell; it being immoveably fixed, by a calcareous process, at the hinge.

The Pinnæ are wedge-shaped shells, or somewhat of a triangular form, 
widening from the top, which is narrow and pointed, to the base which is wide and extended.

In Turton's Linné eighteen species of Pinnac are described; and three only have been found to inhabit the British seas.

\section{ORDER THIRD.}

UNITALVE SHELLS

With a regular Spire.

Genus 18th.--ARGONAUTA. Animal a Sepia or Clio; shell univalve, spiral, involute, membranaceous, and unilocular, or consisting of a single apartment or cell. Linn Syst. 317. Plate 7th, fig. 18th.

Habitation. 'The Argonautre have only been found to inhabit the ocean, $\mathrm{K}$ 
and are found among the rocks near the shore, in the Mediterranean and Indian Ocean.

The Argonauta argo is the Nautilus so famous amongst the ancients, and often mentioned in the writings of Pliny and others. It is supposed that in the earliest ages of society, this shell sugrested to men the first idea of using sails. In calm weather it rises to the surface of the water, (which it does by discharging a quantity of fluid, that rendered it specifcally heavier than the sea-water, and spreads its arms over the shell, which answer the purpose of oars; it then throws out and expands a double membrane, which it can oblique in any direction at pleasure, this answers the purpose of a sail, and by this it is impelled forward by the breeze, like a ship under sail; two of its arms hang over the sbell, and serve as rudders or oars, to direct its course. In the 
event of danger it immediately withdraws within its cell, and sinks to the bottom.

Lamarck proposes two distinct genera of the Argonauta. 'The first is exemplified by the Argonauta Argo of Linné; the second is constituted by the Argonauta Vitreus of Gmelin, and he terms it Carinaria: It is somewhat remarkable, that the great Linné should have been completely at a loss where to place this shell; and in the twelfth edition of the Systema Naturæ, we find it placed among the $\mathrm{Pi}$ tilla, under the title of Patella Cristata, to which tribe it bears no resemblance. It was by Gmelin, with more propriety placed among the Argonauta; but even in this situation it seems misplaced, and I concur with Lamarck in the propriety of forming a new genus with it. Lamarck terms it the Carinaria. 
In Turton's Cinné five species of this genus are described; none of which have been found to inhabit the British seas.

Genus 19th.---NAUTILUS. Animal (Rumphfius Mus.table 17, fig. B;) shell univalve, divided into several departments, communicating with each other by a sephunculus or aperture. Linn. Syst. 318. Plate 7th, fig. 19th.

The Linnean Nautili are divided into two families: *spiral and rounded, **elongated and straight. Of the former there are two sections: †whorls contiguous, $\uparrow+$ whorls separated.

Ilabitation. With a very few exceptions the Nautili have only been found to inhabit the ocean.

Some modern authors propose to divide this genus into three: Nautilus, Spirula, and Orthocrea.

Many of the Nautili are found in a fossil state; see Parkinson's Organic Remains, vol, 3. 
In Turton's Linné thirty-one species of this genus are described; seventeen species have been found on the British coast; and the greatest number of them was discovered by George Montagu, Esq. author of the Testacea Britannica, which is by far the best work on Conchology in the English language.

Genus 20th.--CONUS. Animal a Limax; shell univalve, convolute, turbinate; aperture effuse, longitudinal, linear, without teeth, entire at the base; pillar smooth. Linn. Syst. 319. Plate 8th, fig. 20.

This genus in the Linnean System is divided into five families: *truncati, \&c. having the spire or turban nearly truncate or flat; *** pyriformis, \&c. pyriform, with the base rotundate, and sub-cylindrical, the cylinder one half longer than the spire; ****elongate, with the base rotundate, cylinder twice the length of the spire; ${ }^{*}{ }^{*} * * *{ }^{*}$ ven 
tricose in the middle, and narrow at

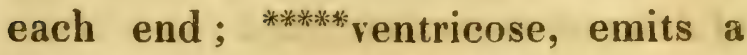
tinkling sound when thrown on its back upon a table.

Habitation. The Cones have only been found to inhabit the ocean, and are generally found on rocky shores.

This genus is a very good one, and well defined by Linné. Although it contains a great many species, none have been found among them to differ so much, as to allow any one to attempt a new genus from it.

Many of the Cones are very beautiful. These shells, in general, are the highest priced of all shells, as they are very rare. One species, the Cedo Nulli of Lyonet, is valued at one hundred guineas. Very few perfect specimens of this shell are known; and those are only to be met with in the most valuable cabinets.

In Parkinson's Organic Remains, vol. 3, several curious specimens are 
described; many of them from the chalk cliffs in Hampshire.

In Turton's Linné seventy-one species of cones are described; none of this genus have been found to inhabit the British seas.

Genus 21st.--CYPREA (or Cowry.) Animal a Slug; shell univalve, involute, sub-ovate, smooth, obtuse at each end; aperture effuse at each end, linear, extending the whole length of the shell, and dentated or toothed on each side. Linn. Syst. 320. Plate 8th, fig. 21.

Linné divides the genus Cypræa into four families: *mucronatæ, or pointed; **htuse, and without any manifest spire; *** umbilicated, or with

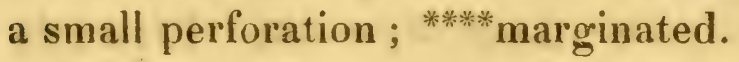

The genus Cypræa consists of beautifully coloured, and very highly polished shells. It is said, that all the $\mathbf{C y}$ proa leave their shells annually, and construct new and larger ones. But 
we have not been able to ascertain this point as a fact.

Ilabitation. 'They live in sand at the bottom of the sea; and the animals are provided with a membrane, which they throw over their shells, which preserves the fine polish, and prevents other testaceous bodies from fixing on them. The Cypræa have only been found to inhabit the ocean.

In 'Turton's Linné 120 species of Cypraa are described; and only one has been found in the British seas.

Genus 22nd.--BULLA. Animal a Limax; shell univalve, convolute, and unarmed with teeth; aperture a little straitened, oblong, longitudinal, very entire at the base; pillar oblique and smooth. Linn. Syst.321. Plate 8th, fig. 22nd.

Habitation. The shells composing the Bulla genus are found to inhabit the ocean, lakes, rivers, and ditches. Those which inhabit the ocean, are 
found a few inches under the sand. They may be frequently taken alive in little pools, between high and low water-mark, in which they are often seen sporting, with a very rapid motion in the sun-beams.

The animal inhabiting the Bulla is considerably too large for its shell, and cannot contract itself wholly within it, as most other animals can do, which inhabit shells.

The French Conchologists have divided this genus into several new ones; the most prominent of these is the Orum; at the head of which stands Linnés Bulla Ovum.

In Turton's Linné fifty-two species of Bullæe are described; and nineteen species have been found to be indigenous to the British seas, lakes, rivers, Sc.

Genus 23d.--VOLUTA. Animal a Limax; shell single-celled and spiral; aperture without a beak and 
somewhat effuse; pillar twisted or plaited, generally without lips or perforation. Limn. Syst. 322. Plate 8th, fig. $23 d$.

Linné divides this very extensive genus of shells into five distinct families: *aperture or opening entire; **somewhat cylindrical and emargiginate; ***obovate, effuse, and emar-

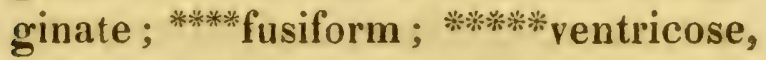
spire papillary at the top.

Habitation. The Volutes have only been found to inhabit the ocean, and are most common in inter-tropical climates.

The French writers on Conchology, have divided the Linnean Volute into several new genera: Oliva, Turbinella, Mitra, Harpa, Musica, and Volva.

In Turton's Linné 144 species of Volutes are described; and eleven species have been found to inhabit the British seas: 
Genus 24th.--BUCCINUM. Animal a limax; shell univalve, spiral, gibbous; aperture ovate, terminating in a short canal leaning to the right, with a retuse beak or projection; pillar-lip expanded. Linn. Syst. 323. Plate 8th, fig. 24th.

The Buccina are divided by Linné into nine families: *ampulla, \&c. inflated, rounded, thin, sub-diaphanous, and brittle; 桊 cassidea, caudata, \&e. with a short, exerted, reflected beak, lip unarmed outwardly; *** cassidea, unguiculated, \&c. lip aculated on the outside of the posterior part ; in other respects resembling the last division; *****callosa, \&c. pillar-lip dilated and thickened; ***** dentrila, \&c. pillar-lip appearing as if worn flat; ******avigata, \&c. smooth, and not enumerated

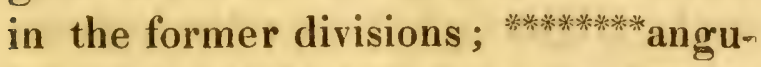
lar, and not included in the former

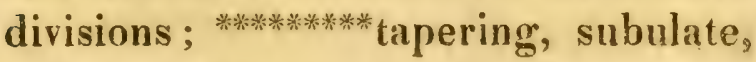
and smooth. 
Ilabitation. The Buccina generally inhabit the ocean, with the exception of a very few species, which are found to inhabit the earth.

Lamarck has divided the genus Buccinum into seven genera: Dolium, Harpa, Cassis,'Terebra, Purpura, Buccinum, and Nassa.

The shells composing the genus Buccinum are in general strong and hollow; they adhere to rocks and stones in the ocean, and deposit their ova in deep water. Some of the larger kinds are said to have been used as trumpets in ancient times.

In 'Turton's Linné 202 species of Buccina are described; and eighteen species have been ascertained to inhabit the British shores.

Genus 25th.---STROMBUS. Animal a Limax: shell univalve and spiral; aperture much dilated; the lip expanding and produced in to a groove 
leaning to the left. Linn. Syst. 324. Plate 8th, fig. 25th.

Linné divides the Strombi into four families: *lip projecting into linear divisions or claws; **lobed; ***dilated; ****tapering, with a very long spire.

Habitation. The shells composing this genus, have only been found to inhabit the ocean; and are in general found on rocky shores. The Strombus Gigas is to be seen, when the water is clear, crawling on the large flat rocks which surround many of the West India islands, at the depth of from fifteen to twenty feet.

The young shells of this genus want the dilated lip, which is one of the most essential characters of the Strom$\mathrm{bi}$, and are in consequence often confounded with the Buccinum and $\mathrm{Mu}$ rex.

The French Conchologists divide the Linnean Strombi into three ge- 
nera : Strombus, Pterocera, and Rostellaria.

In Turton's Linné fifty-five species of Strombi are described; and only two have been found to inhabit the British seas.

Genus 26th.---MUREX. Animal a Limax; shell univalve, spiral, rough, with membraneous sutures; aperture oval, ending in an entire straight or slightly ascending canal. Linn. Syst. 325. Plate 8th, fig. 26th.

Linné divides the Murices into six families: *Spinosi, spinous, with a produced beak; **Frondosi Suturis, sutures expanding into crisped foliations; beak abbreviated; **Ventricose, with thick protuberant rounded sutures; ***Ecaudati, more or less spinous, and without manifest beak ; *****Caudigeri, with a long, straight, subulate, closed beak, and unarmed with spines; ******T Turriti, tapering, subulate, with a very short beak. 
Habitation. The Murices are only found to inhabit the ocean. They in general are to be found on rocky shores, and some of them burrow in the sand.

The shells of this genus are in general thick, strong, and heavy, and often rugged; from which they have obtained the name of rocks in England.

The modern French and German 'Testaceologists, have divided the Linnean Murex into three genera: Fasciolaria, Pleurotoma, and Murex.

The first of these are shells of a fusiform or spindle shape, and smooth, with several oblique folds in the pillar. The Plurotoma are also spindle-shaped, with the aperture terminating in a long canal, lip cleft near the summit. The Murex are those shells of an oval or oblong form, with a canal at the base, and the shell externally beset with prominent, longitudinal ridges, and often tuberculated. 
In Turton's Linné 182 species of Murices are described; and twentytwo species have been ascertained to inhabit the British seas.

Genus 27th.---TROCHUS. Animal a Limax: shell univalve, spiral more or less conic; aperture somewhat angular or rounded, the upper side transverse and contracted; pillar placed obliquely. Linn. Syst. 326. Plate 8th, fig. 27th.

Linné divides the Trochi into three families : *Umbilicate, erect, with pillar perforated ; **Imperforati, imperforate, erect, with the umbilicus closed; ***Turiti, tapering, with an inserted pillar, and falling on the side when placed upon the base.

Habitation. The Trochi have mostly been found to inhabit the ocean, with a few land species. They most frequently live near the shore in pools, or such places as are always 
wet when the tide recedes; some few of them live in very deep water.

Lamarck and Latrellie have made a new genus from the Trochi of Linné, under the name of Pyramidella; the generic character of which is opening, entire, and semi-oval, pillar projecting and raised with three transverse folds, perforated at the base as in the Trochus Dolabratus of Linné. The above writers have formed two other genera, Salarium and Monodonta. The 'Trochus perspectives, or what is called the Staincase Trochus in England, illustrates the first; and Trochus Litbio the second.

In Turton's Linné 133 species are described; and twelve have been found on the British coasts, including one species found on the mountains of Cumberland.

Genus 28th.---TURBO. Animal a Limax; shell univalve, spiral, and solid; aperture contracted, orbicular, 
entire. Linn. Syst. 32\%. Plate 9th, fig. 28th.

The shells composing this genus are divided into five families: *Neritoidei, \&c. with the pillar-margin of the aperture dilated and imperforate; **Solidi, Sc. solid and imperforate; *** Solidi, Sc. solid, perforated;

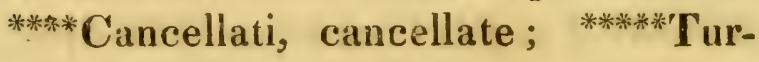
riti, tapering.

Habitation. The shells of this genus are found to inhabit the sea, land, and fresh water; the Turbines adhere to rocks near the shore; and some of them live in very deep water.

The Turbo Scalaris, or wentletrap, as it is termed in England, is very much esteemed by collectors, and is rather a scarce shell. A modern author proposes a new genus from this and similar species; and the longitudinal ribs, he marks as the distinguishing characteristics ; although we must in candour admit, 
that the Linnean Turbo, in its present form, is rather too copious and diffuse, yet we cannot approve of establishing new genera from shells, which differ in so trifling a degree; as genera, established on such flimsy greunds, would be endless.

In Turton's Linné 151 species of Turbines are described; and no less than 69 species have been ascertained as indigenous to Britain.

Genus 29th.--HELIX. Animal a Limax; shell univalve, spiral, subdiaphanous, brittle; aperture contracted, semilunar or roundish. Linn. Syst. 328. Plate 7 th, fig. 29th.

Linné divides the Helices into six families: *ncipites; \&c. angulated on both sides; **arinata, \&c. whorls with a carinate acute margin; *** Rotundata, \&c. whorls rounded and umbilicated ; 然橉rounded and imper-

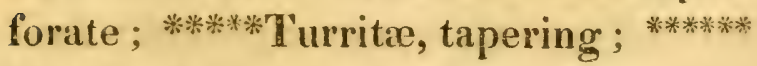
Oratie, \&c. orate and imperforate. 
84

Habitation. The Helices are found to inhabit the ocean, land, rivers, lakes, \&c. They are inhabitants of almost all parts of the globe; and are in general very numerous. On land they are found to inhabit trees, old walls, mossy banks, rocks; and are often found under stones, \&c.

The Helices are termed snails in lingland; they feed on vegetables, \&c. It has been asserted, and on apparently good authority, that snails have been known to revive after remaining in a state of torpidity for about fifteen years; snails are possessed of very considerable reproductive powers, and are capable of regrenerating the head, after it is taken off.

The Helices are a numerous tribe, and many of them are beautifully formed.

Modern Testaceologists have dirided this genus into six genera: Jan- 
thina, Helix, Lymnea, Bulimus, Melania, and Planorbis.

In Turton's Linné 267 species of Iflix are described; and 67 species have been ascertained as indigenous to Britain.

Genus 30th.--NERITA. Animal a Limax; shell univalve, spiral, gibbous, flattish at bottom; aperture semiorbicular, or semilunar; pillar-lip transversely truncate, flattish. Linn. Syst. 329 Plate 9th, fig. 30th.

'This genus is divided into three families : "Umbilicatæ, umbilicate; **Imperforatæ, \&c. imperforate, with the lips toothless; ****Imperforate, with the lips toothed.

Habitation. The Nerita inhabit the sea, lakes, and rivers. Those inhabiting the sea are, for the most part, found near the shore, and several are attached to marine plants; and some are only found in deep water, so that 
live specimens can only be had by trawling for them.

The continental writers on Conchology, Lamarck, Latreille, \&c. have made a new genus from the Nerite, termed Natica, which embraces the umbilicated kinds, such as the Glaucina and its corresponding species. We, however, can see no particular reason for making this a generic distinction. The Linnean Nerita is a very good genus, and there is nothing in the general character of any of the species, which can perplex even a young student. We think it tends rather to retard than to advance the progress of the science, to construct new genera, where there are not strong motives for doing so.

In Turton's Linné 76 species of Nerites are described; and eight species have been found indigenous to Britain.

Genus 31st.--HALIOTIS. Ani- 
mal a Limax; shell ear-shaped, univalve, and dilated, with a longitudinal row of orifices along the surface; spire lateral, and nearly concealed. Linn. Syst. 330. Plate 9th, fig. 3lst.

Habitation. The shells composing the genus Haliotis, have only been found to inhabit the sea. They adhere closely to rocks, and can only be removed by suddenly snatching them from their hold. In some places the animal inhabitant is esteemed good eating. One species, the Ilaliotis Tuberculata, is very common in Guernsey.

The shells of this genus are so very distinct, that they can hardly be mistaken, the Helix Haleotida, indeed, approaches very near to the Ilaliotis, but it wants the most striking characteristic, the longitudinal series of orifices; in other respects it is very similar to the Haliotis, having a pearlaceous inside, and being ear-shaped. 
On the other hand, its prominent spire certainly removes it from this genus.

Gmelen has placed the Hilex Perversa and the Maliotidia, both imperforate shells, among the Haliotis tribe, in his edition of the Systema Natura; and quotes Chemnitz, as authority for so doing: but we think he would have been less blameable, had he constituted a new genus of these imperforate shells.

Heblins, Lamarck, Latreille, and other continental writers, have made a new genus of the imperforate shells, and named it Stomatia, with the following generic character : "shell of an oval form, ear-shaped; spire prominent; aperture ample, entire, oblong ; disk imperforate."

There is no genus of shells which has been so often misplaced as the Haliotis. Lister places it between the Trochus and Nerita, Gualtieri among the snails with depressed spires, Adan- 
son in the first genus of spiral shells; and Da Casta, going still further from the point, places it as his second genus of simple shells.

We see no situation in the present arrangement so well adapted to this genus, as the one it now occupies. It is the most simple of the spiral shells, consequently it now stands in its proper place, as the last of the spiral shells, preceding those shells destitute of a recular spire.

It is asserted, that as a new hole is added by the animal to the shell, it carefully closes up the next open one to the spire; by which means the number of orifices are, in general, the same in all shells of one species.

In Turton's Linné 19 species of Haliotis are described; and only one has been found to inhabit the British seas. 


\section{DIVISION SECOND.}

Shells without a regular spire.

Genus 32nd.--PATELLA. Amimal a Limax; shell univalve, subconic, shaped like a bason; without a spire. Linn. Syst. 331. Plate 9th, fig. 32.

Linné divides this genus into five families: *Labiatr, \&c. furnished with an internal lip; shell entire; **Dentatæ, \&c. with the margin angular or irregularly toothed; ****Mucronatx, \&c. with a pointed recurved tip or

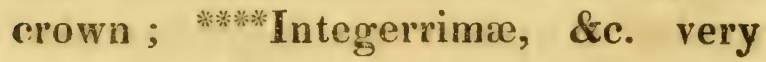
entire, and not pointed at the tip or vertex; ${ }^{*}{ }^{*} * w^{*} *$ Perforatæ, \&c. with the crown perforated.

Habitation. This tribe of shells have been found to inhabit the sea, Iakes, and rivers. Those of the sea in general adhere to rocks and stones 
on the shore; and are so tenacious, that they cannot be removed without breaking the shell, unless taken by surprise. Those inhabiting fresh water are generally found adhering to aquatic plants. The Patellæ are called limpets in England.

The Patella is a very good genus, though there are several authors who dispute this point. We cannot see that the distinctive characters Lamarck has chosen, are sufficient reason for the formation of new genera; their division into sections appear's to us quite sufficient; for with the exception of the chambered limpets, they are all perfectly simple shells, and very like each other.

Lamarck forms the Patellæ into six genera: Patella, Tissurella, Emarginula, Concholepas, Crepidula, and Calyptrae.

In Turton's Linné no less than 240 species of Limpets are described; 
and fourteen species have been ascertained to be indigenous to Britain.

Genus 33d.--DENTALIUM. Animal a Terebella; shell univalve, tubular, straight or slightly curved, with cavity undivided, and open at both ends. Linn. Syst. 332. Plate 9th, fig. 33d.

Fabitation. The shells of this genus are only found to inhabit the ocean. They are solitary, and are to be found immersed in the mud, in an oblique or perpendicular position.--And the shores are those which have flat extended beaches, and on which a quantity of soft mud is collected, commonly known by the name of sludge. 'This genus is unquestionably simple, and very distinct and perfect. Continental 'lestaceologists have also endearoured to overturn this genus, but whout effect. It is defined with too much precision and simplicity to be altered. 
The shells of this genus are known in England by the name of tooth-sholls, or sea teeth.

In 'Turton's Linné 22 species of Bentalium are described; and seven have been found to inhabit the British coasts.

Genus 3th...-SERPULA. Ani. mal a Terebella; shell univalve, tubular, grenerally adhering to other substances; often separated internally by divisions at uncertain distances. Linn. Syst. 333. Plate 9th, fig. 31.

Mabitation. The Serpule have only been found to inbabit the ocean. They are generally found adhering to stones, shells, and plants, \&c. sometimes a plurality of species are found on one stone or shell. There are also several species of Serpula which are unattached.

There have been several attempts to divide and amend the Linnean Serpula, which is certainly a very irregu- 
lar genus; but none of those are by any means satisfactory. Mr. Montagu in his Testacea Britannica has divided this genus into two, under the names Serpula, which are shells attached to other bodies; and $\overline{V e r}$ maculum, shells unattached. But in this division the generic characters are no more definite than that of Linné.

In Turton's Linné 48 species of Serpula are described; and 27 species are ascertained to be inhabitants of the British seas.

Genus 35th.-.-TEREDO. Amimal a Terebella, with two calcareous, hemispherical valves cut off before, and two lancentate ones: shell tapering, flexous, and capable of penctrating wood. Lima. Syst. 334. Plate 9th, fig. 35 .

Ilabitation. The shells of this genus inhabit the bottoms of ships; and oak poles, which are under water in harbours, \&c. One species has 
been found in the mud, at the bottom of the ocean. This last mentioned shell is the Teredo Gigantea, and has been described to be five feet four inches in length, nine inches in circumference at the larger end, and two and one half inches at the smaller. See Philosophical Transactions of the Royal Society for 1810.

The Teredo Navalis has been termed, in this country, the ship worm; it insinuates itself into the bottoms of ships, even although the oak is perfectly sound, and in a very short time completely destroys it. This destructive creature was originally brought by our vessels from tropical climates; but has now become an inhabitant of most of the harbours of this island, and is very common in Plymouth Dock.

We think it has been pretty clearly proved by that learned and very indefatigable naturalist, George Montagu, 
Esq. in his supplement to Testace Britamica, that the animal inhabiting the Teredo, is not a Terebella, but an Ascidea.

There are three species of this shell described in 'Turton's Linnè ; and one has been found to inhabit the British seas.

Genus 30th.--.5ABELLA. Animal a Nereis, with a ringent mouth, and two thicker tentacula behind the head; shell tubular, composed of particles of sand, broken shells, and vegetable substances, united to a membrane by a glutinous cement.

Ifabitation. The shells, (if they can be called so) according to Linné inhabit the sea and fresh water ditches, \&c.

The shells of this genus cannot with propriety he called testaceous, no: are they crustaceous, but coverings made up of extraneous substances; and may therefore fairly be expunged 
from the collection of the Testaceologist. I shall give an extract from the eighth vol. of the Linnean'Transactions, being the concluding paragraph of the catalogue of British shells, the joint labours of Dr. Maton and the Rev. Mr. Rackett; which is a work of great merit, and indispensable to the collector of British shells.

"We venture so far to dissent from the great authority of Linneus, as to exclude from this descriptive catalogue of British Testacea the genus Sabella. The animals included under that genus, have for their coverings particles of sand agglutinated on the external membrane, and resemble rather the larve of certain insects, than the testaceous vermes. The latter form their calcareous integuments entirely from the secretions of their own surfaces, and are attached to these by cartilaginous processes, so as to render them essential and indispen. 
sable parts of their structure. The coverings of the Sabella seem to be more of an adventitious nature, and may be considered rather as serving the purposes, than as being organized integrals of the contained animal.-If these ideas be correct, the genus Sabella does not come within our province."

In Turton's Linné 25 species of Sabellæe are described; and Mr. Montagu has discovered 12 on the British coasts.

\section{- \\ SPECIFIC DESCRIPTION \\ OF THE \\ $\mathbb{P I} \mathscr{A} \mathbb{T} \mathbb{E} S$.

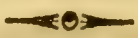 \\ PLATE 1 .}

MULTIVALVE SHELLS.

Fig. 1st.-.-LEPAS RUGOSA.-With a sub-cylindric shell, usually 


\section{OF CONCHOLOGT.}

six furrows, which frequently widen towards the top, and terminate in angulated points, sometimes as wide as at the base; compartments sulcated, or sometimes striated longitudinally; of a yellowish colour ; operculum consisting of four rough, angulated, erect valves.

Linn. Trans. vol. viii. page 25.

$A$ operculum, $B$ the base, $F F$ ridges or furrows, $I$ a stone to which the base of the shell is affixed.

Fig. 2nd.--LEPAS ANA'TIFERA. Shell compressed, with five obsoletely striated valves; the lower valves somewhat triangular; the superior ones long, and tapering to an obtuse point. The valves connected by a cartilage, of a reddish colour, and affixed to a peduncle of a colour between vermillion and orange.

This shell is generally affixed to pieces of rotten wood and to the bottoms of vessels, and is found in almost 
all seas. Found plentifully on the sides of the New Bason, Leith.

Linn. Trans. vol. viii, page 28.

$\boldsymbol{B} B$ base, $C C$ peduncle, $D D D$ ligament, $\boldsymbol{E} \boldsymbol{E}$ feelers, $\boldsymbol{G}$ a piece of wood to which the peduncle is affixed.

Fig. 3d. represents a spoon for lifting fresh water shells. It is made of white iron of a circular form, and five inches in diameter, concave, and perforated with small holes to allow the water to escape; they must be very small, The margin should be surrounded with a perpendicular rim of about half an inch in height. Some of the fresh water shells being extremely minute, of course will pass through with the water, if the holes are too large. There is a hollow handle to the spoon, which should be fitted to the point of a walking stick: and it may be put into the pocket when not used. This spoon will be found very useful, in taking shells which sel- 
dom can be come at, without some assistance of the kind. It should always be carried in the pocket, when a person goes a-walking; and in botanizing excursions, when in search of aquatic plants, a few rare shells may be at same time picked up in ditches, \&c. It must be understood, that shells which inhabit fresh water, from their colour are very difficult to be seen in their places of abode, being in general so much like the bottom of the ditches; of course the collector is not to content himself with only taking those shells he can observe, but must frequently rake the bottom, and also among plants, and weeds, when he will in general find shells which were hidden from his view. In very fine sunshine days in summer, shells which inhabit fresh water, are either floating on the surface of the water, or crawling on aquatic plants : and land shells, are generally seen crawling abroad in 
dewy mornings, or after a gentle shower of rain.

\section{BIVALVE.}

\section{Fig. 4th...-VENUS CHIONE.}

Shell strong, sub-cordated, somewhat concentrically wrinkled, margin entire, covered with a smooth, glossy, chesnut-coloured epidermis ; sometimes a little radiated; beneath which the shell is of a beautiful pale purple; apex turned sideways, with a cordiform depression; umb̄o placed nearest one end. Found at Falmouth in Cornwall.

Linn. Trans. vol, viii. page 84 .

$a a$ Summit, $b b$ lunule, $i$ anterior slope, $k$ posterior slope, $o$ disk, $p$ margin or limb.

Fig. 5th.-.-SOLEN SILIQUA. Shell linear, straight; in one valve two teeth, and one in the other, with a lateral inclined tooth corresponding 
with the opposite lanina; with a fine olivaceous brown epidermis, very glossy, with transverse strix which takes a longitudinal direction across the shell. Common on most sandy shores.

Linn. Trans. vol. viii. page 43.

$v v$ Breadth of the shell, $u u$ length of the shell.

\section{Fig. 6th--VENUS COMPRESSA.}

Shell strong, thick, sub-orbicular, compressed, and slightly sulcated or irregularly wrinkled; colour white, but is usually covered by a thick yellowish-brown epidermis; umbo prominent, turning to one side, beneath which is a small cordiform depression; hinge with two teeth in one valve, and a transverse one.

$c$ Sides, $d$ base, $e e$ cicatrix, $g g$ teeth of the hinge, $v$ the umbo.

Supp. to Testa. Brit. page 43.

Fig. 7th.---ANOMIA EPHIP. PIUM. Shell sub-orbicular, irregu- 
larly wrinkled, and waved; upper valve convex, under flat and perforated at the hinge, through which the ligament passes by which it is affixed to other bodies; inside pearlaceous, and of various changing colours ; green purple, violet or yellow.

Often to be met with adhering to the common oyster, or ostrea maxima.

Linn. Trans. vol. viii. page 102.

$a$ Base, $m$ ligament perforation.

Fig. 8th.--VENUS DECUSSATA. Shell ovate, with decussate striæ, angular before ; ape $x$ turned to one side ; umbo placed nearest one end; hinge furnished with three teeth in one valve; posterior slope very minute and retuse; anterior slope long and narrow, with generally an inner blue margin. The outside is commonly of a plain rusty brown, and marked with purple zigzag lines.

Linn. Trans. vol. viii. page 88. 
a Summit, e e cicatrix, $g g g$ teeth of the hinge, $n$ the inside.

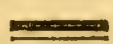 \\ PLATE $\mathbb{I I}$ 。}

BI VAL VE SHELLS.

Fig. 1st.---SOLEN ANTIQUATUS. Shell thin, white, and subpellucid; moderately glossy, with concentric striæ; ends rounded and gaping; hinge near the centre, furnished with a single tooth in one valve looking in between two in the opposite, the teeth are erect, oblique, and stand beyond the margin; outside covered with an umber-coluured epidermis. Found on the Cornwall and Dorsetshire coasts, \&c.

Linn. Trans. vol. viii. page 46.

$l$ The cartilage, $n$ inside, $p$ margin or limb, $q$ hinge. 
Fig. 2nd.-.OSTRLA LAEVIS. Shell thin, flat, sub-orbicular, and pellucid, longitudinally and transversely striated; one ear considerably larger than the other; colour various, sometimes orange, dark pink, \&c. Not uncommon on the coast of Northumberland. The strix on this shell is so minute, that it can seldom be seen with the naked eye.

Linn. 'Trans. vol. viii. page 100.

$f$ Longitudinal and transverse striæ, $\hbar \hbar$ ears or auricles.

Fig. 3d.--TELEINA FABULA. Shell very thin, pellucid and oval, generally of a dull yellow, and darker towards the umbo; which is nearly central, pointed, and turned a little to one side; the anterior side slopes to an obtuse point, the posterior side is large and ronnded; hinge furnished with three teeth in one valve and two in the other.

This shell is often mistaken for the 
Tellina Tenuis, to which it bears some resemblance, but may be easily distinguished from that shell, by the right valve being covered with a fine, regular, diagonal stria; which is not conspicuous without the assistance of a lens, which makes it appear very plain. Not uncommon on the coasts of Northumberland, Dorsetshire, and Devonshire.

Linn. Trans. vol. viii. pagre'52.

l. Cartilage, q q hinge.

Fig. 4th.--MVTHUS EDURIS.

Shell oblong, pointed at the beak, sides much sloped; anterior side a little angulated; smooth and radiated with deep blue, or purple; covered with an umber-coloured epidermis. Inside, round the margin, of a fine blue, which grows gradually lighter towards the centre; cicatrix very distinct and glossy; beneath the beak are several crenulations, which some have supposed to be teeth. This is the most 
common shell we have, and well known by the name of muscle.

Linn. Trans. vol. viii. page 105.

$l$ The cartilage, $v v$ length of the shell, $u u$ breadth of the shell.

Fig. 5th.--CHAMA COR. Shell sub-globose, beaks recurved; anterior slope with a gaping fent, slightly wrinkled transversely, covered with a terra sienna coloured epidermis; umbo large and prominent, much contorted or incurvated, and turned to one side, and not touching when the valves are closed; hinge strong, teeth flattish. Inside smooth, white; margin plain. This is a very scarce British shell; and has been found off the North Foreland, the Hebrides, and off St. Abb's Head by Captain Laskey.

Linn. Trans vol. viii. page 90. o Disk, $r \boldsymbol{r}$ beak.

Fig. 6th.--NYTILUS EDULIS. See description at fig. $4 \mathrm{th}$. $s$ The byssus or beard, $t \boldsymbol{t}$ seam. 
OF CONCHOLOGY.

109

UNIVAL TE SHELLS.

Fig. 7th.--VOLUTA OLIVA. Shell smooth and glossy; spire reflected at the base; pillar with four plaits; clouded, or covered with zigzag or waved lines of a pale brown colour. Found in the Indian seas, in endless varieties of colours and markings.

Linn. Syst. Natura, vol. ii. page 1188. Turton's Linné, vol. iv. page 326.

$A$ :Apex, $I$ front, $N$ outer lip, $Z$ plaits of the pillar lip or columella.

Fig 8th.---HELIX VIVIPARA. Shell with six ventricose whorls, separated by a deep depressed line, subovate and obtuse, of an olive-green, with generally three fasci or bands on the body of the shell, and two on the superior volutions, which become obscure in the fourth, slightly wrinkled transversely: aperture sub-orbicular: 
pillar-lip reflected: sub-umbilicated. Found in the Thames and New River.

Linn. Trans. vol. viii. page 205.

$A$ Apex, $\boldsymbol{B}$ base, $\boldsymbol{L}$ a whorl, $\boldsymbol{r} \boldsymbol{r}$ bands or fasci.

Fig. 9th.--HELIX POLITA. Shell strong, white, glossy and smooth, with from nine to twelve volutions, scarcely defined by a separating line, slender and gradually tapering to a point; aperture oval, outer lip thick, but not marginated, inner or pillar-lip replicated. Found in Devonshire, Dorsetshire, Northumberland, and at Dunbar in Scotland.

Linn. Trans. vol. viii. page 210.

$A$ A pex, $B$ base, $\mathbb{E}$ suture of the spire or whorls, $\mathbb{C}$ aperture.

Fig. 10th.--BUCCINUM UNDATUM. Shell with from seven to eight ventricose volutions, with undulated ribs; transversely striated, and crossed with five longitudinal striæ; pillar-lip reflected, and glabrous. 
A common shell on many of the British shores.

Linn. Trans. vol. viii. page $13 \%$.

F Body, M M the pillar or columella, $Q$ canal or gutter.

Fig. 11 th.---MUREX MURICA'TUS. Shell strong and rough, with from six to seven ventricose, tuberculated volutions, tapering to a fine point; the tubercles are formed by interrupted, longitudinal ribs, crossed by strong elevated strix, and in some parts are pointed or angulated; apex smooth; aperture oval, terminating in a long slender canal; outer-lip sharp and dentated at the edge, margin within crenulated; pillar-lip smooth. Rather a local shell.

Montagu's Testacea Britannica, page 262.

Linn. Trans. vol. viii. page 149.

$B$ Base, $C$ aperture, $\mathbb{K} K \&$ \&c. sides, $P$ the heak or rostrum, Q canal or gutter. 
Fig.12th.--CONUS VARIA. Rubbed through on one side to show the internal structure of the shell.

$\boldsymbol{D}$ spire, $\boldsymbol{F}$ body, $\boldsymbol{M} \boldsymbol{M} \boldsymbol{M}$ pillar or columella.

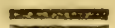 \\ PLATE III.}

Fig. 3d.---TROCHUS UMBILICATUS. Shell conico-convex, flattish, rounded at the top; apex depressed, volutions five, slightly emarginate, defined by a fine line; spirally striate, rather whitish, with zigzag lines of purple; aperture compressed and angulated; with a large mbilicus which extends to the apex. Found on the Northumberland and Yorkshire coasts.

Linn. Trans, vol. viii. page 153.

$C$ Aperture, $U$ umbilicus.

Fig. 2d.--HERIX NEMORALIS. Shell imperforate sub-globose, thin 
and sub-pellucid, colour various; volutions five, with from one to five dark brown bands or fascice; aperture pyriform ; inner margin of the lip, sometimes white, in others dark-reddish brown. This shell is very common in the evenings and mornings in summer, at the roots of hedges, \&c.

Linn. Trans. vol. viii. page 206.

$\boldsymbol{N}$ Oater lip, $\boldsymbol{X}$ epidermis, $\boldsymbol{Y}$ epidermis removed.

Fig. 3d.--NAUTILUS POMPILIUS, with the lip cut straight to show the involuted spire.

$C$ Aperture, $\boldsymbol{T}$ involuted spire.

Fig. 4th.--The OPERCULUM of a Turbo.

Fig. 5th.--HELIX GLUTINOSA. Shell suborbicular, thin, and diapha. nous, of a glossy, pale horn-colour, smooth, but sometimes with obsolete wrinkles; the body very large; spire very small; volutions three; aperture. ery large, extending nearly to the 
apex. Found by Mr. Montagu, in the marshes at Deal.

Linn. Trans. vol. viii. page 222.

$G$ 'The back, $I$ the venter or belly, $S$ depressed spire.

Fig. 6th.-.PATELLA CHINEN. SIS. Shell sub-conic, sub-pellucid, and very thin, colour whitish, much compressed, rounded at the margin; vertex central, terminating in a subspiral volution, with usually a number of concave scales. Inside white, glossy, and smooth, with a sub-spiral columella or pillar-lip, extending from nearly the margin to the end, and forming the external sub-volution; it is broad, flat and oblique.

Found in Helford harbour, Cornwall; in Salcomb bay, Devonshire, by Mr. Montagu; and near Dunbar, by Captain Laskey.

Iinn. Trans. vol. viii. page 28. W Chamber. 


\section{Fig. 7th.---HELIX SUBULATA.}

Shell tapering and subulate, very smooth, and glossy; whorls about ten, and scarcely defined; colour white, with two pale-chesnut spiral lines running from the body to the apex, becoming very faint on the upper whorls; aperture ovate, and rather contracted. Length thre quarters of an inch.

Found at Weymouth and neàr Dunbar, by Captain Laskey.

Linn. Trans. vol. viii. page 210.

D Spire, $\mathbf{F}$ body.

Fig. 8th.---STROMBUS PUGI-

LIS. Anterior lip prominent, rounded, smooth; spire spinous; beak three, lobed, obtuse, flesh-colonred, reddish or brownish, within paler and polished; back smooth ; first whorl of the spire crowned with spines, which in the other grow gradually less; the ontermost whorl cancellate; pillarlip much reflected. 
Inhabits South America, and the shores of the West India islands.

Linn. Syst. Naturæ, page $\mathbf{1 2 0 9}$.

Turton's Linnè, vol. 4th, page 420.

$D$ Spire, I front, $\boldsymbol{N} \boldsymbol{N} \boldsymbol{N}$ the outer lip, $O$ pillar-lip, $Q$ canal or gutter.

Fig. 9th.--TURBO TEREBRA. Rubbed through in the back to show the pillar or columella.

Linn. Trans. vol. viii. page 176. Body, MMM columella.

Fig. 10th.---HELIX PUTRIS.--Shell sub-pellucid, and horn-coloured; spire with four volutions; the body tumid and large, apex very small; apex fine and pointed, wrinkled longitudinally; aperture oval and large, outer-lip very thin; outside covered with a dusky epidermis, inside pale, yellow, and very glossy.

Common in most ponds, ditches, \&c.

Linn. Trans. vol. viii. page 219.

$G$ The back, $\boldsymbol{H}$ the venter, $\boldsymbol{L}$ whorl or volution. 
Fig. 11th.---NAUTILUS SPIRULA. Aperture of the shell orbicular; whorls cylindrical, separated, and gradually decreasing inwards, the first a little straight siphunculus contiguous to the walls of the shell; outside of a pale cream colour, within pearlaceous.

Inhabits the American and Indian oceans.

Linn. Syst. Naturæ, page 1163.

Turton's Linnè, vol. 4 th, page $30 \%$.

$\boldsymbol{N}$ Spicula, $\boldsymbol{V}$ siphunculus, $\boldsymbol{W} \boldsymbol{W W}$ $W W$ chambers.

Fig. 12th.--TURBO COSTATUS. Shell sub-pellucid, white and subturrited; volutions five, with prominent, longitudinal ribs, a little oblique ; apex obtuse; aperture sub-orbicular, with a thick sulcated margin.

Found in Pembrokeshire, Dorsetshire, and Northumberland.

Linn. Trans. vol. viii. page 174.

$\boldsymbol{R} \boldsymbol{R} \boldsymbol{R} R$ Ribs. 
Fig. 13ih.-.TURBO LABIA'TUS. Shell with nine reversed volutions or whorls, tapering to a fine point; colour light brown, with strong, regular, longitudinal strix; volutions fat, and separated by a fine obsolete line; aperture sub-orbicular and white, with a sinus at the upper end, with two teeth-like lamina on the inner lip; margin reflected, broad and thick. Found in Hyde Park, and the ozier grounds at Battersea in Surrev.

Linn. Trans. vol. viii. page 130.

$b$ Reversed or beterostrophe spire, $a$ teeth of a univalve.

Fig. 14 th.--HELIX PLANORBIS. Shell depressed and sub-pellucid, horn-coloured, rufous, or light chesnut brown; generally with a light umbercoloured epidermis; volutions five, placed laterally on each other, gradually decreasing to the centre, making the shell concave at top, rounded and defined by the suture; subulated 
across the whorls; a carinated ridge round the margin at the base; aperture angulated, and slanting towards the base.

Linn. Trans. vol. viii. page 188.

Not uncommon in ponds, rivers, and ditches: they are of a very large size at Prestwick-water, near Neweastle on Tyne.

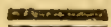 \\ PLATE IV}

HINGES OF BItALVES, \&c.

Fig 1st. Hinge of the Mya Pictorum. a Primary tooth, $c c$ double teeth.

Fig. 2nd. Hinge of the Solen Siliqua. b Lateral teeth.

Fig. 3d. Hinge of the Tellina Radula. a a Primary teeth, $n$ cartilage. 
Fig. 4th. Hinge of the Cardium Aculeatum. b Lateral tooth, $d d$ middle teeth, $l l$ spines.

Fig. 5th. Hinge of Mactra Hians.

Fig. 6 th. Inside of both valves of the Donax Trunculus. 1 Left valve, $B$ right valve, $b$ lateral teeth, $e$ primary complicated tooth, or cleft in the middle, $n m$ crenulated margin.

Fig. 7th. Hinge of Venus Gallina. a $a$ Primary teeth, $b$ lateral tooth.

Fig. 8th. Hinge of Spondylus Gexderopus. If Incurved teeth.

Fig. 9th. Hinge of Chama Cor.

Fig. 10th. Hinge of Arca Pilosa. $k k$ Numerous small teeth; the distinguishing characteristic of the genus Arca.

Fig. 11th. Hinge of Ostrea Varia. $g$ Cavity of the hinge, $h$ superior ear, $i$ inferior ear.

Fig. 12th. Mlinge of Anomia Iphippium. 
OF CONCHOLOGT.

\section{PLATE V.}

To illustrate the Genera.

MULTIVALVE SHELLS.

Fig. 1st. Chiton Marginatus.

2nd. Lepas Tintinnabulum.

3rd. Pholas Crispatus.

BIVAL VE SHELLS.

Fig. 4th. Mya Arenaria.

5th. Solen Ensis.

6th. Tellina Donacina.

7th. Cardium Edulis.

\section{PLATE VI.}

Fig. 8th. Mactra Lutraria. 9th. Donax Trunculus. 10th. Venus Aurea.

11th. Spondylus Gæderopus."

Those shells marked * are forcigu.

R, 


\section{Fig. 12th. Chama Cor.}

13th. Arca Noæ.

\subsection{0 \\ PIATE VII.}

Fig. 14th. Ostrea Opercularis.

15th. Anomia Undulata.

16th. Mytilus Incurvatus.

17th. Pinna Muricata.

UNIVALVE SHELLS.

Fig. 18th. Argonauta Argo.*

19th. Nautilus Pompilius."

\section{PLATF VIII.}

Fig. 20th. Conus Striatus.*

21st. Cypraa Pediculus.

22nd. Bulla Catina.

23rd. Voluta Eiscopalis.*

24th. Baccinume Lapillus.

25th. Strombus Pes Pelicani. 
OF CONCHOLOGY.

Fig. 26th Murex Antiquus.

27th. Trochus Papillosas.

\section{PLATE IX.}

Fig. 28th. Turbo Rudis.

29th. Helix Arbustorum.

30th. Nerita Littoralis.

31st. Haliotis Tuberculata.

32nd. Patella Vulgata.

33rd. Dentalium Entailis.

34th. Serpula 'Triquetra.

35th. Teredo Navalis.

36th. Sabella 'Tubiformis.

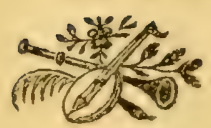




\title{
II II $\mathbb{S}$
}

\author{
OF THE
}

\section{PRINCIPAL BOOKS}

WHICH TREAT OF

\section{Conchologe.}

"The 'Systema Naturæe of Linné." 12th edition, published at Stockholm, 1767 , in 4 vols. 8 ro.

A Translation of the Systema Nature, by Dr. Turton, published at Wondon in 1806, in 7 vols. 8vo. with all the discoveries since the time of Linné. The shells are contained in the 4 th vol.

Martin Lister's 'Synopsis Methodica Conchyliorum, published in parts from 1685 to 1622. The plates in the most perfect copies vary from 7050 to $106 \%$. The plates of this 
valuable work were left to the college of Oxford; at which place it was republished in 1770, in folio; the plates are in number 1085, containing 1150 shells, and a considerable quantity of plates of fossils.

'Recreatis mentis et oculi in observatione Animalium 'Testaceorum, a Phil. Bonanné, published at Rome in 1684, 4to; contains a great many plates of different shells; many of them are, however, reversed, which makes them of little value in referring to.

'Geo. Everp. Rumphius Thesaurus Imarginum Piscium 'Testaceorum, 1711, folio, contains 38 plates on shells.

- Descriptio Thesauri Rerum Naturlium,' published at Amsterdam in 1758, vol. 3rd, contains 61 plates on Conchology.

D'Argenville's ' L'histoire naturelle eclaircie dans une de ses parties prin- 
cipales, la Conchyliogie,' Paris 175\%, 4to. 'The same in an improved state, in 5 vols. 1 to. Raris, 1780.

Francois Michael Regenfuss's 'Natural History of Testacea and Crustacea,' Copenhagen, 1758--'78, folio.

Martine's Work on Conchology, with the Continuation of F. H. Chemnitz, in 10 vols, 4to. published at Nurnberg in 1769, \&e.

Thomas Pennant's British Zoology, vol. 4th.

E. M. Da Costa's 'Elements of Conchology,' London, 1776, 8 vo.

E. M. Da Costa's 'British Conchology,' London, 1778, 4to.

George Walker's work ' On Minute British Shells,' contains 5 plates, London, 1784, 4to.

John Lightfoot's 'Account of some minute British Shells,' Phil. Trans. vol. 76.

Adams 'Description of minute 
Shells found in Pembrokeshire ; Linn. Trans. vol. 3rd. and 5th.

J. Donovan's, 'Natural History of British Shells, in 5 vols. royal 8 vo. London, 1799, \&c. This work contains 180 coloured plates of British shells.

George Montagu's 'Testacea Britannica, published at London, in 1803, 1 vol. 4 to. with a supplement. These two vols. contain 30 plates, principally minute shells.

Dr. Maton, and the Rev. Mr. Rackett's Descriptive Catalogue of British Shells, in the 8th vol. of the Linnean Transactions, with 5 plates of rare shells.

To the British Collector this vol. is indispensibly necessary, as it contains a list of every shell discovered to the time of its publication; described in the most correct and elegant style. litse learned and ingenious authors 
have corrected the errors of all writers who preceded them.

Captain Laskey's Catalogue of Shells found by him in North Britain, in the 1st vol. of the Memoirs of the Wernerian Society, with one plate containing 17 species of very rare shells. To this gentlemen the British Testaceologist is indebted for the discovery of no less than 50 new species of British shells.

Perry's Conchology, in one vol. folio. This work contains about 52 coloured plates, well executed : but it is to be regretted, he gives no reference to any other author.

Parkinson's 'Organic Remains,' 3rd. vol. contains an account of many shells found in a fossil state, with a great many figures. 
OF CONCHOLOGY.

\section{DRIETHODD}

OF

\section{CLEANING SHELLS, \&}

Shells can only be expected perfect, when they are found with the animal alive in them, or taken by the dredge or trawling-net from their native beds; fine specimens are sometimes found adhering to fishermen's lines or nets. After violent storms many excellent specimens are often found on the beach, driven from their beds by the agitation of the waters; on such occasions perfect specimens are often to be met with; the Conchologist ought, therefore, to avail himself of every opportunity, of walking along the beach, immediately after the tide begins to recede. The greater 
part of shells seen in collections, are picked up dead on the beach, and are therefore seldom very perfect, as they are rossed to and fro by the waves, and either worn or broken; and should they even be driven beyond the reach of the tide, in this situation they are exposed to the continual heat of the sun, by which their colours become faded.

River and land shells are mostly thinner than those of the sea: though this is by no means a general rule, as the Paper Nautilus, some of the Ilelices, and Pinnx, are extremely thin and brittle.

Several of the land shells are very beautiful, and elegant in their form, particularly those found in tropical climates In Africa they grow to an amazing size, and would be very unwelcome guests in our house gardens, as they commit great havoc among the esculent plants. The Bulla Ze- 
bra of Africa, is very frequently found seven inches from the apex to the base. A few of cur own land shells are very beautiful; but from their being familiarized to us, we look on them with the greatest indifierence; for example, the Helices, Pomatia, Arbustorum, and Nemoralis.

Some authors affirm, that the $\mathbf{C y}$ praa tribe abandon their shells every year, to form new ones of a larger size; but this seems rather a doubthal circumstance.

When shells are found with the animal in them, hot water sbould be poured upon the shells, and the animal dies, and may be easily taken from bivalve shells; but caution is required in the univalves; as should part of the animal be left in the volutions, it will be almost impossible to extract it ; and the smell becomes very offensive.

Shells are to be met with, on almost every shore in the known world, but 
those of warm climates bare in general a finer polish, and exceed all ochers in point of colouring.

There is great deception practised by the dealers in shells, by which means they easily impose on those who are unacquainted with them. If a shell happens to have the lip broken, they take a common file, and form it anew; thereby the character of the shell is completely altered. Some go so far as even to form a canal, to imitate rare shells, and also counterfeit stria: when they have accomplished this, they then imitate the external colouring; and finish the whole by a coat of varnish. The shlis they thus transfurm are, in general, worn specimens, which are of no earthly use; though in some instunces good shells are sacrificed to obtain their ends.

Mluch might be here said on the arts pracised to alter, pach up, and beautify shells; but this has no con. 
nexion with the science, and may therefore with much propriety be omitted, as a Naturalist would prefer a worn, or even a broken specimen, to one either altered, or coloured and varnished; to improve it, and make it pleasing to the eye. Surely the lover of nature must look with contempt on all artificial means, employed either to alter or amend the sacred works of nature. It will be sufficient to point out the means of simply cleaning testaceous bodies.

When shells are perforated by sea worns, or when any other accidental circumstance occurs, to deform a good specimen, it is certainly desirable to use some means to improve it; and for this purpose a putty may be made of fine whitening, flowr, and gluc; the holes or cracks may be filled up with this composition, and allowed to ary; it should always be a little above the surface, and cautiously scraped 
down with a knife; when, ridges or strix can easily be imitated, if necessary. 'The parts thus mended may be coloured with common water colours, and then brushed; or if on a smooth shell, polished with the palm of the hand, and afterwards rubbed over with Florence oil, which should be well dricd off with a piece of flannel. If this mode is judiciously managed, it may be examined, and never discovered.

Many shells, even when obtained alive, are incrusted with extraneous matter: the best and safest means of removing this is, first to steep them in warm water, and then to scrape them with a linife; a little sand paper may also be used, but care must be taken not to injure the shell. When as much of the crust is in this way removed, as can with safety be done, recourse should be had to mariatic acid, very much diluted with water; by applying 
this cautiously with a feather, to the places you wish removed, for a very short period, it will soon decompose the extraneous matter: two minutes at a time is as long as it can with safety be applied, but one minure's application often has the desired effect: it should then be immersed in cold water, and the parts well scrubbed with a nail-brush and soap. Should the crust not be entirely removed, this process may be repeated, but the greatest care is to be used not to allow the acid to touch the inside, as it will instantly remove the fine enamelled surface. Some are so cautious as to melt bees' wax, and coat the parts of the shell they do not wish touched with the acid.

When water is used too hot, in the first process, it often makes the fine polished surface crack in a thousand directions.

After the process of corrosion, some 
make use of flannel or a brush, and emery or tripoly, to polish the shell. This may be done in cases where the polished insides happen to be touched with the corrosive fluid; but in all instances where the places cleared by the acid, are of a white or chalky appearance, they should be washed over with Florence oil, and then rubbed hard with flannel or a nailbrush. This mode gives the shell the appearance of nature, and at same time stops the action of the acid, should any remain in the shell, and is of great use in preserving it from decay. It is of infinite use in preserving the epidermis, which often, when it becomes dry from lying long in a cabinet, cracks and quits the external surface of the shell. It would not be amiss to rub them orer with oil once a year.

This practice of oiling shells is a new one, and I believe I was the first 
who thought of it, and have communicated it to all my friends who collect shells; and it has been generally approved. Hadeed one friend, who had a very large collection, was so pleased with the effect it produced, that he washed off the gum from all his shells, and oiled them. The common practise of collectors is, when they obtain a specimen which is a little worn, to coat it over with a solution of gum arabic, which certainly heightens the colours; but the gloss is by no means natural, and a judge may in a moment discover the deception. This varnishing system is carried to a great length by some, who have almost every shell in their cabinets daubed over with gum arabic, and they all shine with great lustre, even although many of the shells should themselves be dim in a natural state. 


\section{Simple Method of Arranging} Cabinets.

TinE most simple method of arranging cabinets, is, by cutting white cards into the size you wish the boxes, (if they may be so termed;) then take a pair of steel dividers which are fixed with a screw, and set them to the size the depth of the sides is wished; place the card upon a piece of pasteboard, and draw the dividers along the surface, one leg being guided by the edge of the card; press pretty hard so as to make a deep groore; then cut out the corners, and press up the sides, which will be found to stand quite stiff; but if great nicety is wanted, a piece of paper may be pasted on the corners. On the bottom of every box should be written the name of the shell it contains, with the place it was found in ; a reference to some author who describes it; and such other remarks as may be thought necessary. 
OF CONCHOLOGY.

Explanation of Cerms

USED IN THE

\section{SCIENCE OF CONCHOLOGY}

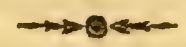

A

Abrievinted, shorter than some correspondent part.

Acini, granulations.

Acuelate, furnished with, or ending in, prickles.

Acuminated, ending in a sharp point, sharp pointed.

Adnate, adhering or growing together, adjoining.

Equilateral, where the anterior and posterior shells are equal in size and figure.

Aquivalve, where both valves are perfectly similar. 
Alated, winged, applied to the ex. panded lip of the Strombus genus. Ambitus, the circumference or ontline of the valves.

Annulate, formed or divided into distinct rings, or marked with differently-coloured annulations.

Antiquated, longitudinally furrowed, but interrupted by transverse furrows, as if the shell had acquired new growth at cach furrow.

Anus, a depression on the posterior side near the hinge of bisalves.

Aperture, the mouth or opening of the shell.

A pex, the tip or point of the spire. A pophysis, an exerescence.

Approximating, approaching near to, or near together.

Arcuater, bent in the form of an arch, incurvated.

Arcuations, bendings, curvings.

Area, the surface contained between lines or boundaries. 
Arenose, sandy.

Articulations, junctures, or joinings.

Ascititious, supplemental, additional. Attenuated, thin, slender.

Attiguous, hard by.

Attrite, worn by rubbing:

Aurated, eared, having ears as in the scallops.

Auricled, having appendages like ears. $B$.

Barb, any thing that grows in place of a beard.

Base, in univalves that part of the shell by which they are afficed to rocks, \&c. and in multivalves the opposite extremity to the apex.

Biangulated, having two corners or angles.

Beak, the continuation of the body of univalves in which the canal is situate.

Beard, the process by which some univalves adhere to rocks, \&c. Bellying, distended in the middle. 
Bidented, having two teeth.

Bifarious, parting in opposite direction's.

Bifid, opening with a cleft.

Bilabiate, furnished both with an outer and inner lip.

Bilobate, divided into two lobes.

Bimarginate, furnished with a double margin as far as the lip.

Biradiate, consisting of two rays.

Biralve, consisting of two valves or divisions.

Blotched, spotted in an irregular way. Blunt, obtuse, opposite to acute. Blush, of a red colour.

Borer, a piercer.

Brinded, streaked.

Bulging, gibbous, swollen out.

Bullate, of a blistered appearance.

Bunt, an increasing cavity, a tunnel. Byssus, a beard, common in the Mytilus and Pinna. 


\section{C.}

Calcareous, relating to lime, of a limy nature.

Callus, is composed of two short ribs, united at the base, and converging at the apex towards the hinder part of the shell.

Campanulate, shaped like a bell.

Canaliculated, made like a pipe or gutter

Cancellated, surrounded with arched longitudinal ribs.

Cancelled, latticed, or having longitudinal streaks or furrows, decussate by transverse ones.

Capacious, wide, vast, extended.

Carinate, having a longitudinal prominence like the keel of a vessel.

Carinated, keeled.

Cartilage, a flexible fibrous substance by which the valves are united, situate near the beak.

Cauda, the elongated base of the ventre, lip and columella. 
Cicatrix, the glossy impression in the inside of the valves, to which the muscles of the animal have been affixed:

Ciliate, edged with parallel hairs, bristles or appendages.

Cinerous, of ash colour, of the colour of wood ashes.

Cleft, divided in the centre, cloven.

Clovate, thicker towards the top, elongated towards the base.

Clivulus, a little cliff, or descent.

Coated, furnished with an outer deciduous covering.

Cochlex, shells of one piece, univalves. Cochleate, twisted like a screw or the shell of a snail.

Columella, the upright pillar in the centre of most of the univalve shells. Commissure, a joint, a seam, a mould. Complicate, membranaceous, bent to an acute angle, as in the tooth of the Mactra, \&c.

Complicated, doubled together. 
Compressed, squeezed together, one valve in general flatter than the other.

Concamerated, arched over, vaulted Concamerations, the apartments of the Nautili.

Concave, hollowed out like a bowl. Concentric, running to a centre.

Conchæ, shells consisting of two or more pieces or valves, bivalves, multivalves.

Cone, the form of a sugar-loaf.

Confluent, running into one channel.

Conoid, a figure like a cone, sugarloaf-shaped.

Contorted, twisted, or incumbent on each other, in an oblique direction. Contracted, shortened, shrunk up. Convoluted, rolled upon itself, twisted spirally, like a piece of paper rolled between the finger and thumb.

Cordate, heart-shaped.

Cordiform, resembling the form of a heart. 
Coriaceous, of a leather-like consistance.

Corneous, of a horn colour, resembling a horn.

Coronated, crowned, or girt towards the apex with a single row of eminences.

Costated, ribbed, baving large ribs. Corpus, the body of the shell, the last or great wreath in which the aperture is situate.

Cortex, the anterior skin or epidermis. Corticated, covered with an epidermis. Crenated, notched at the margin, or scalloped.

Crenulated, notched, jagged as some leaves are.

Crispated, rough with waving lines. Cuneiform, shaped like a wedge.

Cylindrical, round like a roller. D.

Decorticated, worn, divested of epidermis or skin.

Decussated, generally applied to striæ, 
which is crossed, or intersects each other at acute angles.

Dentile, a small tooth, such as the tooth of a saw.

Denticulated, set with small teeth, as in the Arca.

Depressed, pressed down, low, shallow, flat.

Dexter valve, is the right valve.

Diagonal, a line from angle to angle. Diaphanous, transparent, clear, pellucid.

Digitated, fingered or clawed, as in the lobes of the outer lip of the Strombi, \&c.

Disk, the middle part of the valves or that which lies between the umbo and the margin.

Divaricated, straddling, spreading out widely.

Divergent, tending to various parts, from one point.

Dorsum, the back, it generally means the upper surface of the body of the 


\section{8}

shell, when laid upon the aperture or opening. In the genera of $\mathrm{Pa}$ tella and Haliotis, the back means the upper convex surface.

Dotted, punctured like a thimble.

Dual, expressire of the number two.

Duplicated, deeply divided as if bifid.

Duplicature, a fold, any thing doubled.

Duodecuple, consisting of twelve, twelve fold.

\section{E.}

Echinated, bristled like a hedge-hog, set with spines.

Effuse, generally applied to where the aperture is not whole behind, but the lips are seperated by a gap so that water poured in runs out at it.

Elliptical, having the form of an ellipsis, oval.

Elongated, lengthened, drawn out.

Emarginate, to take away the margin or edge of any thing; without a margin.

Ensiform, two-edged, sabre-shaped, 
and tapering towards the point like a sabre.

Entire, whole, undivided, not broken. Epidermis, the outer coat of the shell, which is found in many species; which often falls off of its own accord without any injury to the surface of the shell; the beauty of many shells is hidden by this outer coat. Equidistant, being at the same distance.

Equilateral, having all sides equal. Equitans, folded one upon another Essential character, is a single circumstance serving to distinguish a genus from every other genus.

Esurine, corroding, eating.

Exoleted, worn or faded.

Expanding, standing in a direction between upright and horizontal.

Extraneous, not belonging, to a particular thing. 
F.

Fasciated, filleted, or corered with bands.

Fascicled, clustered together as in a bundle.

Tastigate, flat and even at top.

Faux, what can be seen of the cavity of the first chamber of the shell, by looking in at the aperture.

Ferruginous, of an iron colour, or rust coloured.

Filament, a slender thread-like process.

Filiform, thread-shaped, slender and of equal thickness.

Fissure, a cleft, a little slit, or narrow chasm.

Flexous, zigzag, with angles gently winding.

Fluviatic, of or belonging to a river.

Foliated, bent into laminæ or leaves. Fornix, the excavated part under the umbo. It likewise signifies the upper, or conrex shell in the Ostea. 
Eragil, brittle, easily broken.

Front, in univalves, when the aperture is turned towards the observer.

Furcated, forked.

Furrow, a small trench or hollow.

Fuscated, darkened, obscured.

Fusiform, spindle-shaped, intermediate between the conical and oval.

\section{G.}

Gap, an opening, in multivalves and bivalves when the valves are shut as in the Pholades, Myce, \&c.

Geminated, marked with a double elevated stiiæ connecting the wreaths. Genus, a distinct division or tribe of any class, which may comprehend many species, or individuals, agreeing in their generic character.

Genera, the plural of genus.

Generic description, consists of an accurate description of the parts composing a shell, and all the shells, whose essential parts agree with this 
description, are species of the same genus.

Gibbous, bulged or bulging.

Glabrous, smooth, of a smooth surface, opposed to hairy, downy, \&c.

Globose, globular.

Granulated, beaded, in small grains or beads.

Groove, a hollow channel.

\section{II.}

Hemispheric, in the shape of a half globe.

Hersute, rough, beset with strong hairs.

Heteroclitical, synonymous with heterostrophe.

Heterostrophe, reversed, applied to shells whose spires turn in a contrary direction to the usual way.

Hisped, beset with rather stiff bristles. Hollow, like a straw.

I.

Jağgुed, denticulated, uneven, toothed like a saw. 
Imbricate, placed over each other at the edges like the tiles of a house. Imperforate, not pierced with a hole, wanting the umbilicus.

Inaquilateral, when the anterior and posterior sides make different angles with the hinge.

Inrequivalve, where one valve is more convex than the other, or dissimilar in other respects, as in the common oyster.

Inarticulate, indistinct, not properly formed.

Incumbent, one lying over the other. Incurvated, bent inwards, crooked.

Indented, unequally marked, such as rows of teeth.

Inflated, tumid, swollen, as if blown out.

Inflected, bent inwards.

Inflexed, bent towards each other.

Internode, the space between one

knot or joint and another.

Interrupted, divided, separated. 
Interstice, space between one part and another, a crevice.

Intortion, the turning or twisting in any particular direction.

Involucel, a small or partial involucre. Involution, that part which involves or inwraps another.

Involuta, where the exterior is lip turned inwards, at the margin, as in all the Cypreæ.

Juncture, the joining of the whorl of the spire, dc.

\section{K.}

Keel, the longitudinal prominence in the Argonautæ.

Knob, a protuberance, any part bluntly arising above the rest.

Inobbed, set with knobs, having protuberances.

L.

Labra, the lip.

Lacinate, jagged or cut into irregular segments. 
Lacunose, having the surface covered with small pits.

Lamillated, divided into distinct plaits or foliations.

Laminæ, thin plaits, one coat laid over another.

Lanceolate, oblong, and gradually tapering to each end like the head of a lance.

Lateral, extending to one side, from the centre.

Lapideous, stony, of the nature of stones.

Watticed, having longitudinal lines or furrows, decussate by transverse ones.

Lenticular, doubly convex, of the form of a lens.

Ligament, the membranaceous substance which connects the valves together.

Limb, the circumference of the valves, within or behind the margin.

Line, a longitudinal extension, it is 
sometimes applied to lines of colour only, at others to a grooved line. Linear, composed of lines, being marked with lines.

lineate, marked with lines.

Lip, the outer edge of the aperture of univalves.

Littoral, of or belonging to the shore. Livid, discoloured, black and blue.

Lobated, rounded at the edges.

Loncritudinal, the length of the shell from the apex to the base.

Lubricity, slipperiness, smoothness of surface.

Lunated, formed like a half moon.

Lunulated, crescent-shaped.

Lunule, a crescent-like mark or spot, situated near the anterior and posterior slopes in bivalve shells.

M.

Margin, the whole circumference or outline of the shell in bivalves.

Narginated, having a prominent margin or border. 
Nembrane, a web of several sorts of fibres.

Membranaceous, consisting of membranes.

Mottled, clouded or spotted with various colours.

Mucronate, ending in a sharp rigid point.

Muricated, clothed with sharp rigid points.

N.

Nemoral, of or belonging to a wood. Nited, glossy.

Nodous, a knot.

Nucleus, a kernel.

Nympha, the cartilage to which the hymen is attached; they are concealed by the hymen.

0 .

$\mathrm{Ob}$, in composition is used for inversely or inverted; as obconic, inversely conic; obcordafe, inversely heart-shaped, \&c.

Oblique, slanting 
Oblong-ovate, oblong egg-shaped.

Obsolete, indistinct, not well defined.

Ccelated, applied to eye-like spots.

Ochreous, resembling ochre.

Ofiuscated, darkened, clouded, dimmed.

Olivaceous, being of an olive colour, resembling olive.

Operculum, a lid by which some of the turbinated univalves close the aperture; and is applied to some of the tops of multivalves.

Orbed, circular, formed in a circle.

Orbicular, spherical, circular, roundish and flat.

Order, a sublivision of a class, or second branch of systematical arrangement.

Orifice, an opening or perforation.

Orate, shaped like the longitudinal section of an egg.

P.

Palmate, webbed, like the feet of some water birds; deeply divided into 
lobes like the fingers on the hand. This character is very conspicuous in some of the Strombi.

Papillous, having the surface covered with dots or pimples.

Papulous, pimply or blistered.

Patulous, with a gap or opening.

Pearlaceous, of or like mother-ofpearl.

Partitions, are calcareous processes, dividing the shells of the Nautili and Serpula into different apartments. Pectinated, resembling a comb, cut into regular straight segments like the teeth of a comb.

Pedicle, the support of the Eepas Anatifera and its corresponding species, by which they are attached to wood, \&c.

Peduncle, synonymous with Pedicle.

Pellicle, the skin or film.

Pellucid, transparent, clear, bright.

Pentacapsular, having five cavities.

Pentædrous, having five sides. 
Pentagonal, having five angles.

Perforated, pierced with holes.

Pervious, admitting passage.

Phosphorescent, emitting light in the dark.

Pillar, the columella, or perpendicular centre which extends from the base to the apex, in most of the spiral shells.

Plaits, folds.

Plicated, folded or plaited, as in the pillar of the volute tribe.

Prismatic, generally applied to the colours of shells, being like those of the prism.

Porcate, marked with raised longitudinal lines.

Protrude, to thrust forward.

Protuberances, plaits higher or more elevated than the parts adjoining.

Punctated, with small dots or punctures like a thimble. 
Q.

Quadrangular, having four right angles.

Quadriplicated, having four plaits.

R.

Radiate, furnished with rays.

Radicated, is when the shell is fixed

by the base to another body.

Rectangular, having right angles.

Recurvated, turned backwards.

Recurved, bowed back.

Reflected, thrown backwards.

Reflexed, the same as recurvated.

Refracted, abruptly bent as if broken.

Reniform, kidney-shaped.

Repand, with a serpentine margin.

Replicated, folded or plaited, so as to

form a groove or channel.

Reticulate, marked like a piece of net work.

Retroflected, bending in different directions.

Retuse, ending in an obtuse sinus:

bluntly notched. 
Retundated, blunted, or turned at the edge.

Reversed spire, is when the volutions are the reverse way of a common cork screw.

Reversed spires, when the spires are turned upwards.

Revolute, rolled backwards.

Ribbed, longitudinal, and sometimes transverse ridges.

Ridge, the upper part of a slope.

Rima, the interstice between the valves, when the hymen is removed.

Rostrated, having a beak; the extension of the shell, in which the canal is situated.

Rotund, round, circular, spherical.

Rudiment, the first part of a thing; generally applied to the indistinct teeth of shells.

Rufous, of a reddish colour.

Rugose, rugged, full of wrinkles. 


\section{S.}

Sanguinaceous, of a blood colour, or resembling blood.

Scabrous, rough, rugged, harsh, or like a file.

Scalloped, indented at the edges.

Scorbiculate, pitted, having the surface covered with hollows.

Scorbiculus, a depression or cavity.

Seam, the line formed by the union of the valves.

Semi-cylindrical, a cylinder cut through lengthways.

Semi-orbiculate, in the shape of a half globe.

Semi-lunar, the shape of a half moon. Semi-pellucid, somewhat pellucid, though not fully so.

Serrated, like the teeth of a common saw.

Serrulated, very minutely serrated.

Setaceous, bristle-shaped.

Sinister valve, is the left valve.

Sinus, a groove or cavity. 
Siphunculus, a cylindrical canal perforating the partitions in polythalamous shells; for instance the $\mathrm{Nau}$ tilus Spirula.

Solitary, generally applied to a single tooth.

Spatulate, rounded and broad at the top, and becoming narrower like a spatula or battledore.

Species, the division of a family or genus, containing such as agree with it in generic characters.

Spiny, thorny, covered with thorn-like processes.

Spire, all the whorls of univalve shells, excepting the one in which the aperture is situated, which is termed the body.

spiral, twisted like a cork screw. Squamous, scaly.

Squarrose, consisting of scales spreading every way, or divided into pieces standing upright and not parallel with the plane. 
Stillate, radicating like the spokes of a wheel.

Striated, scored, or covered with fine thread-like lines.

Sub, in composition, it means almost or approaching to, as sub-globose, somewhat globular.

Subrotund, nearly globular.

Subulate, somewhat awl-shaped, or tapering gradually to a point. Sulcated, furrowed, marked with broad furrows or ridges.

Sulci, furrows or ridges.

Summit, the tip or apex.

Suture, the hollow line which separates the wreaths.

\section{T.}

Taper, gradually tapering to a point. Tentacula, the feelers of worms, which inhabit shells.

Tesselated, chequered like a chess board.

Testacea, the third order of worms, 
including those which are covered with a testaceous shell.

Tetragonal, four cornered.

Torose, swelling into knobs or protuberances.

Transverse, placed across, or crossways.

Truncated, stunted, cut short or abruptly off at the end.

Tubercle, a little knot or pimple.

Tubular, in the shape of a hollow tube.

Tunicated, coated.

Turbinate, shaped like a top or pear. Turgid, swollen.

V.

Valve, the whole of uniralve shells, or shells in one piece; and the half of bivalyes, or shells in two divisions, \&e.

Varices, sutures of the wreaths, transverse and gibbous.

Tariety, is when a shell differs so 
little from another that it cannot be called a distinct species.

Vaulted, like the roof of one's mouth. Venter, the belly, situated in the body of the shell; being the most prominent part, when the aperture is turned to the observer.

Ventricose, inflated, swelling in the middle.

Vertex, in the Patella the top or most prominent part, situated in general nearly in the middle. In the Bulla it is used for the apex.

Verrucose, warted.

Verticulated, whirled.

Umbilicated, having a depression in the centre like a navel.

Umbo, in bivalve shells, the round part which turns over the hinge.

Umbonate, bossed, having a raised knob in the centre.

Undulated, waved, having a waved surface.

Ungulate, shaped like a horse's hoof. 
- 168 THE ELEMENTs, \&c.

Unilocular, with a single cavity.

Univalve, shells of one valve, or complete in one piece.

Volutions, the wreaths, or turnings of the shells of univalves.

Urceolate, swelling in the middle like a pitcher.

Vulva, a spatulated mark in the Venus tribe; formed when the valves are united on the posterior and anterior slopes.

\section{W.}

Whorl, one of the wreaths or turning of the spire of univalves.

\section{Z.}

Zigzag, having contrary turnings and windings.

Zoned, surrounded with one or more girdles.

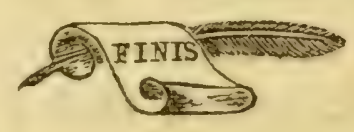

J. Gleare, Printer, Manchester. 
Parts of shells

Plute $1^{\text {st }}$

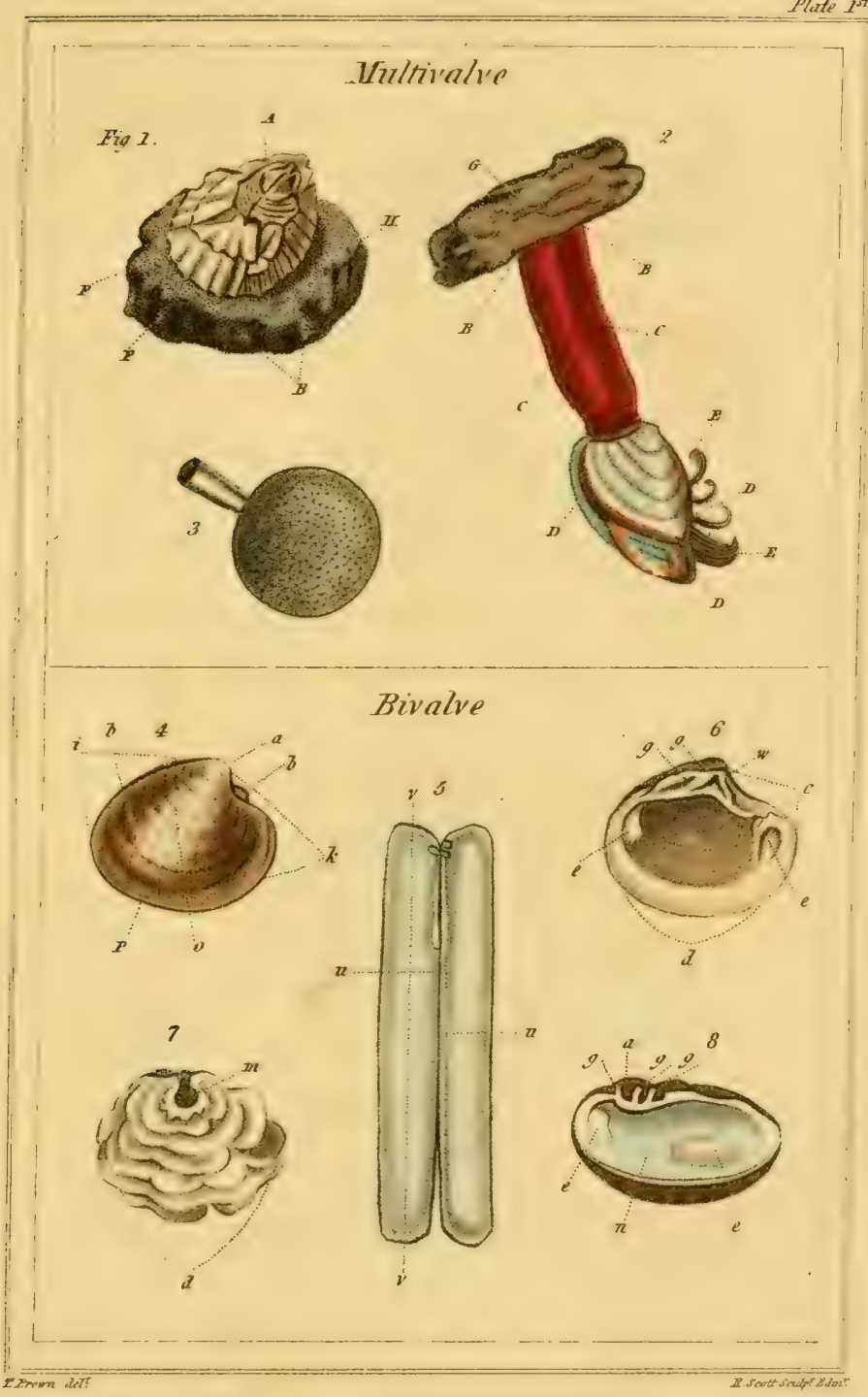



Parts of Shells.

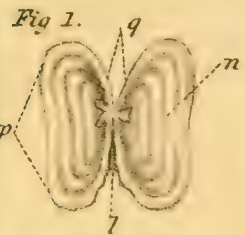

Bivalve
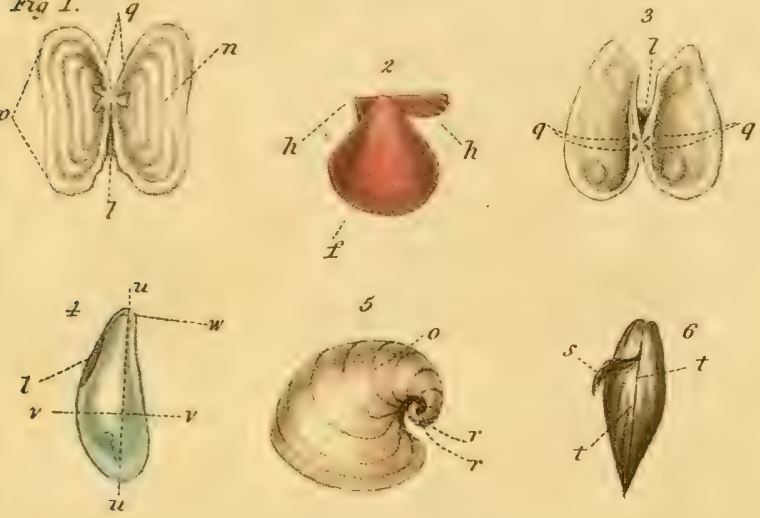

Univalve.
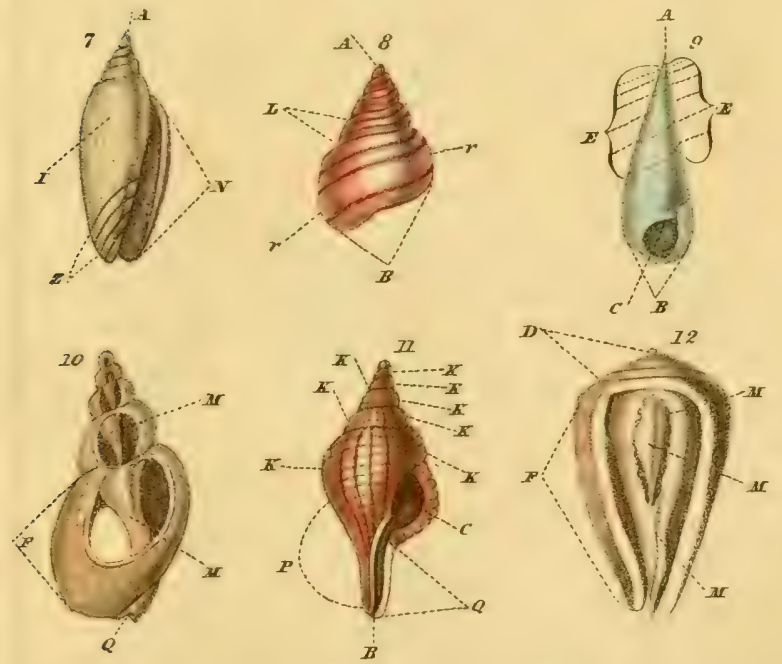

Paits of shells.

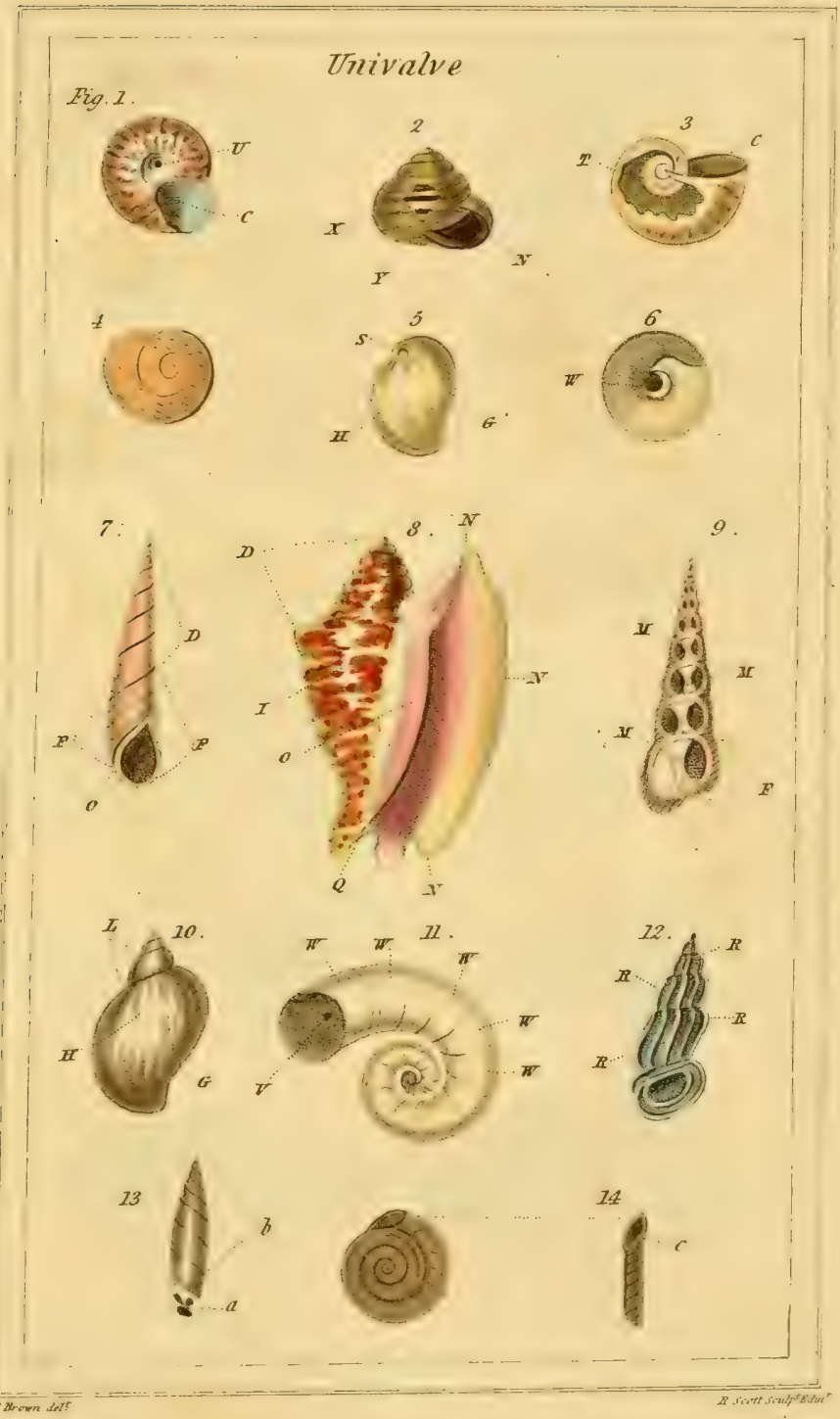



Thinges of Rivalves. Plate $1^{\text {th }}$

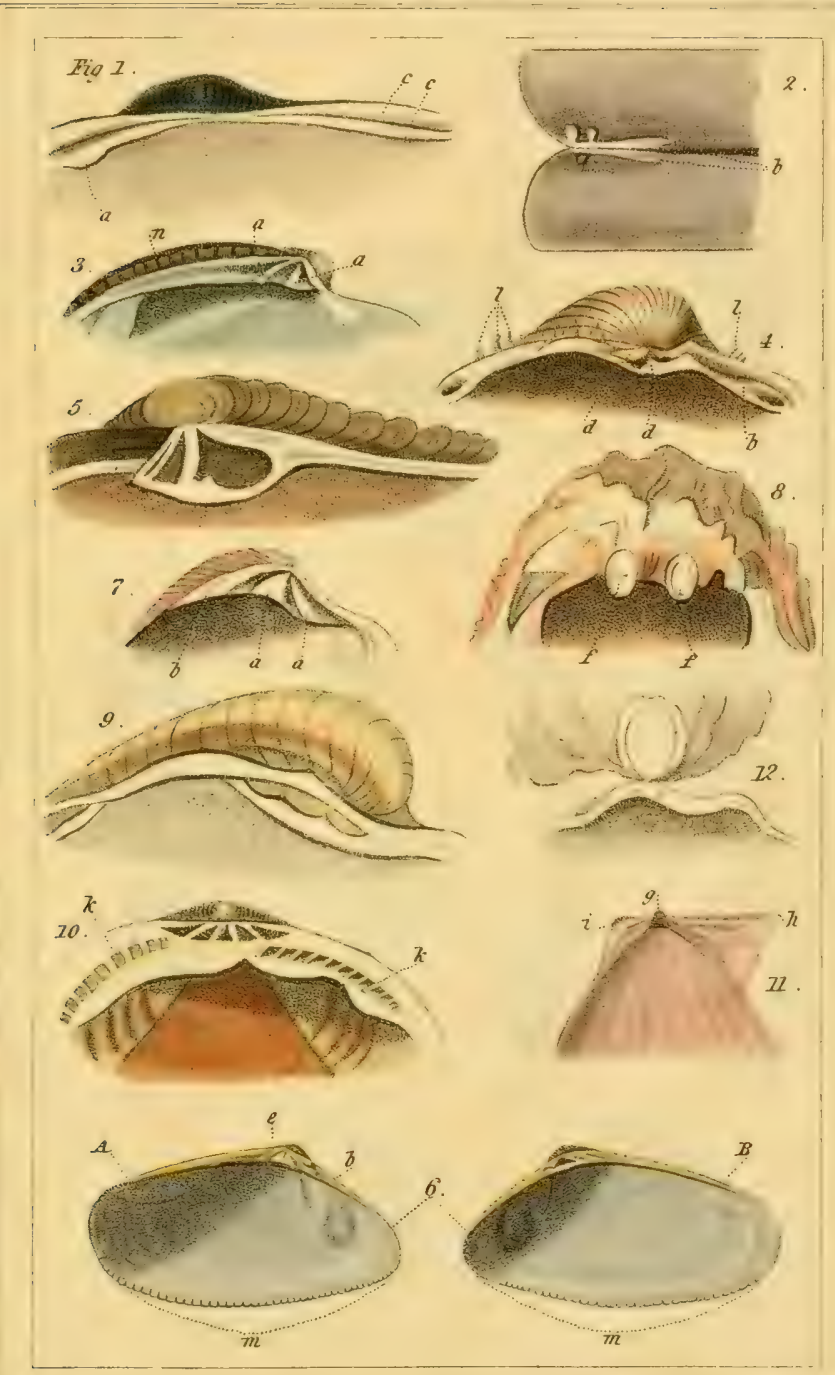



Giment.

Plete : =

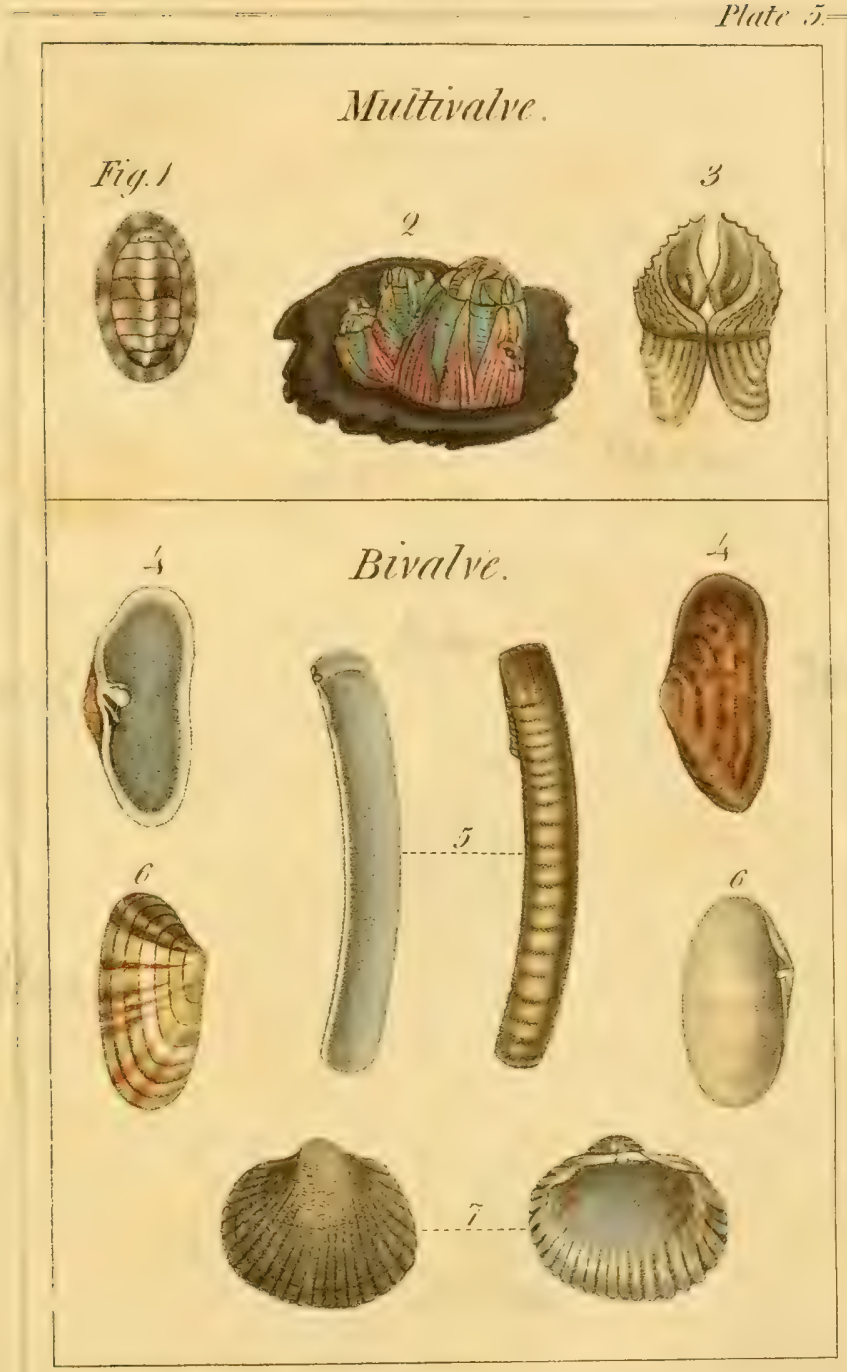

ristrom zel!

ק. Sartt sailpt 

Genera.

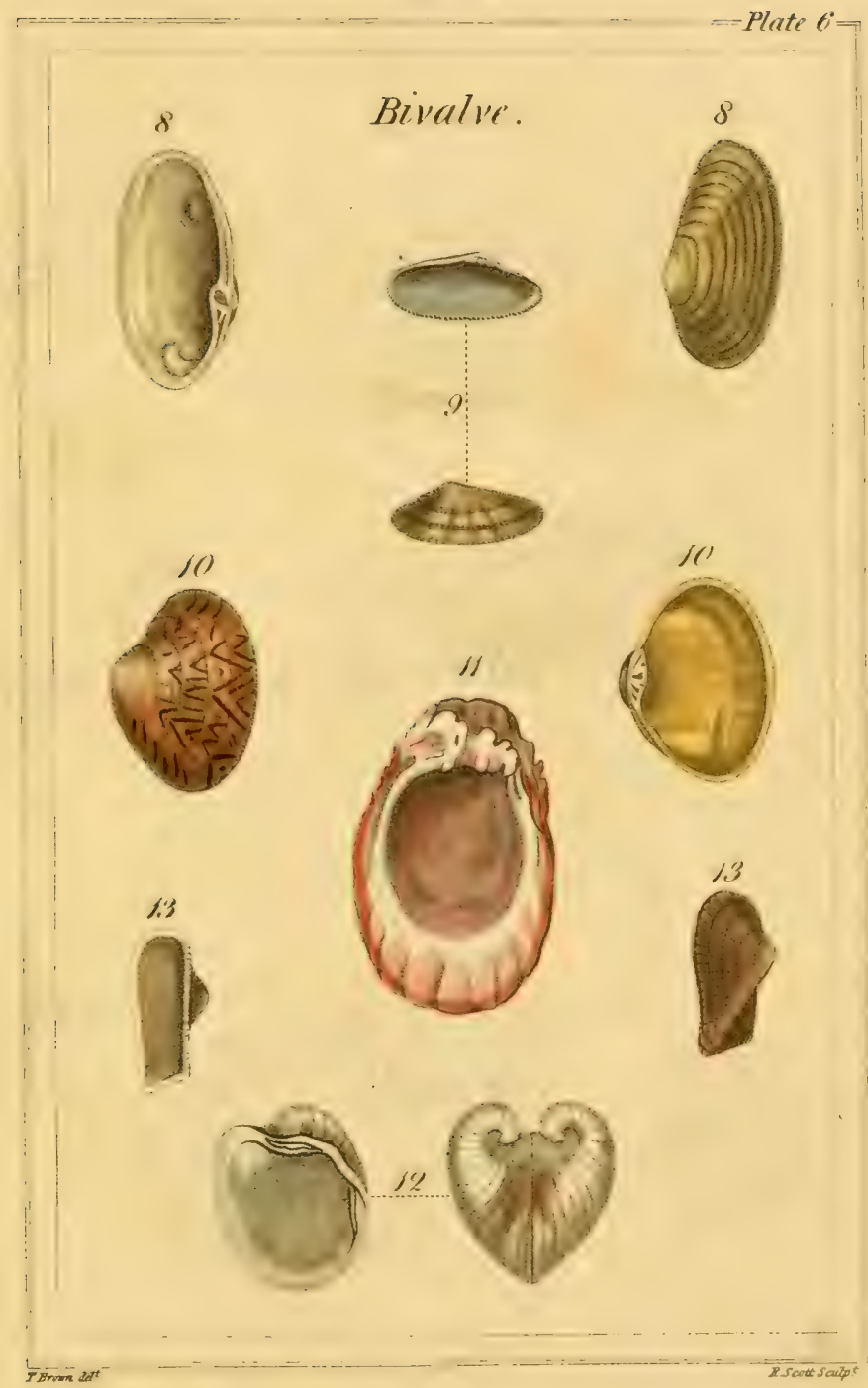


Genera.

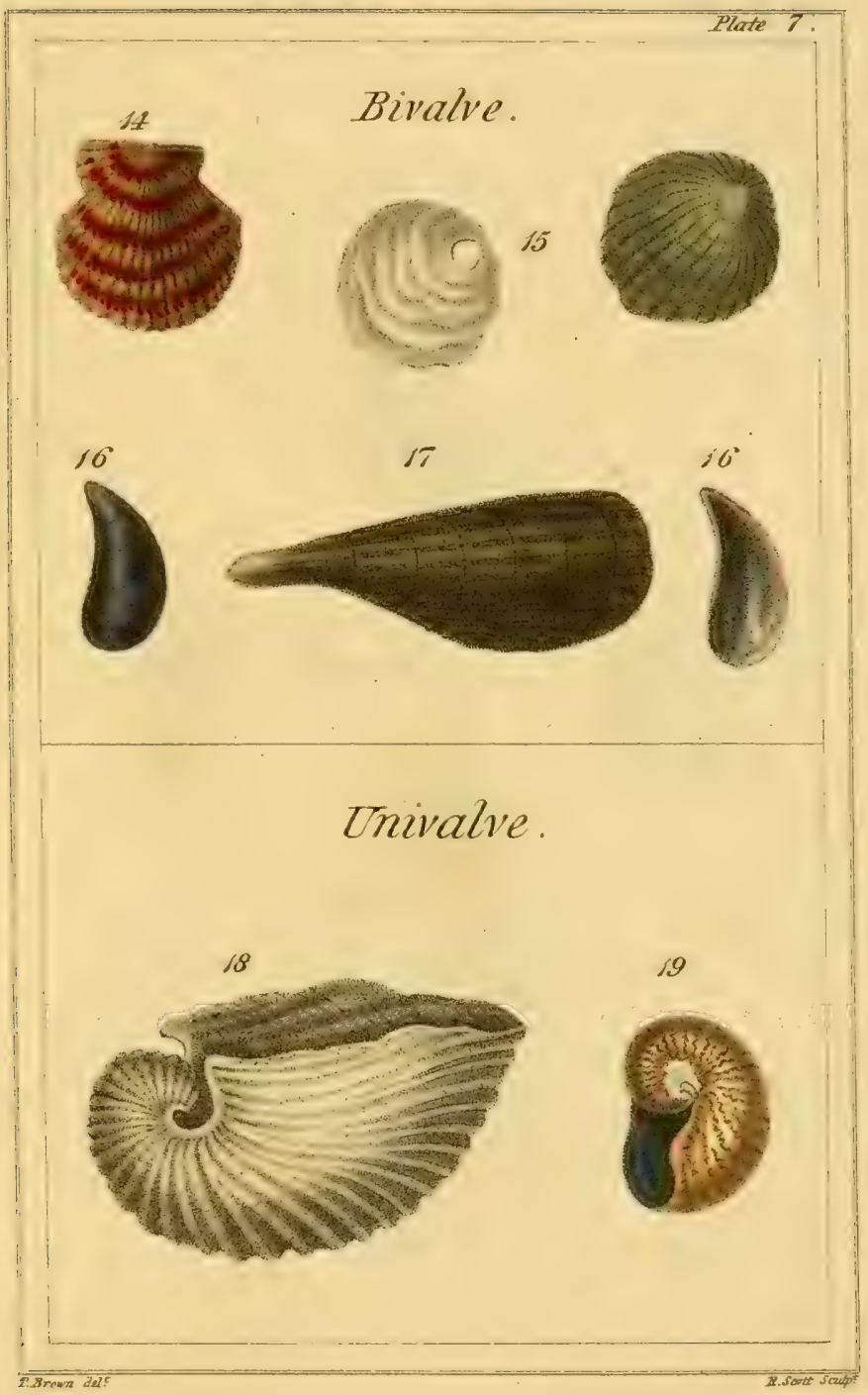



Genera.

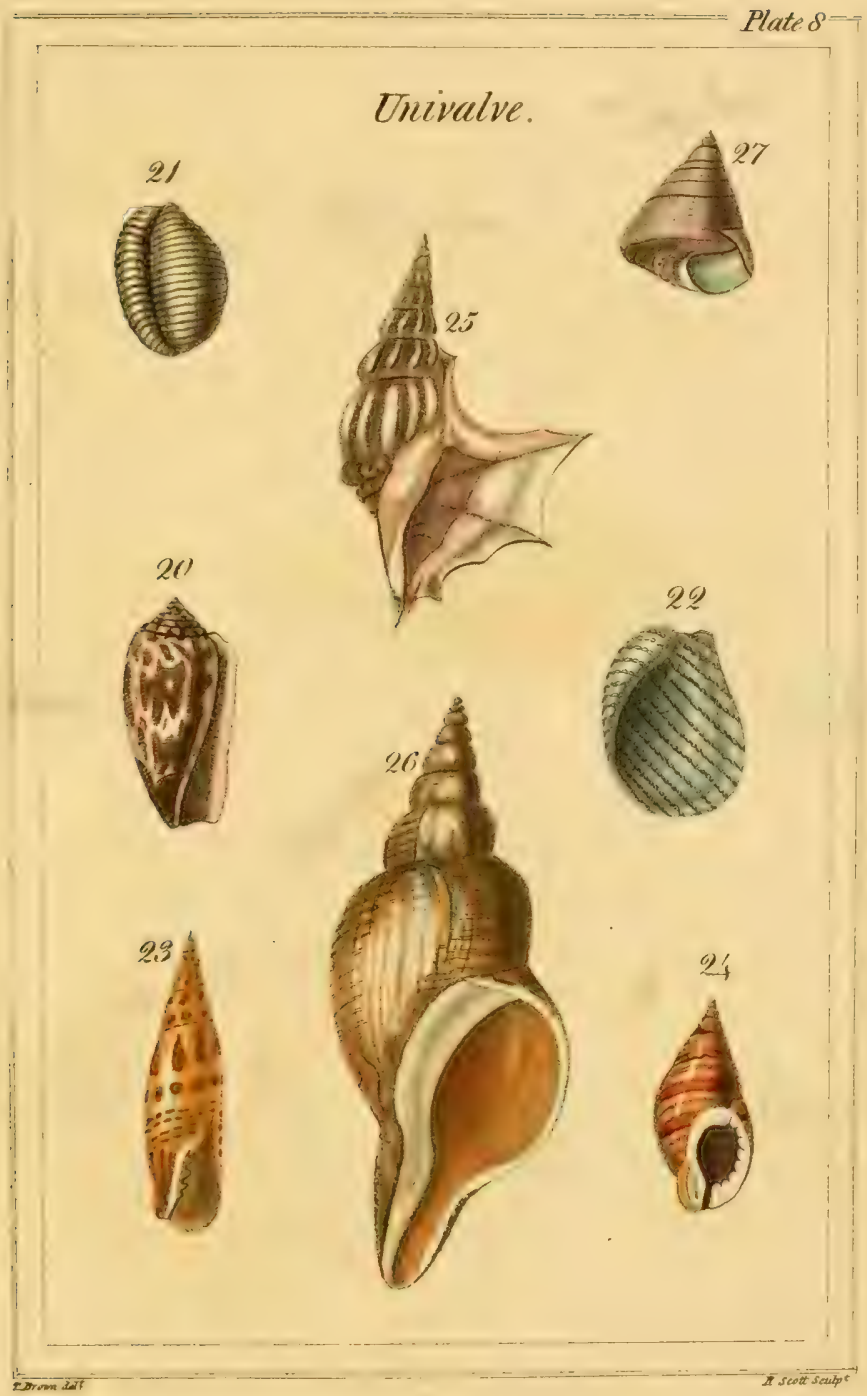




Oarded 

